\title{
The Authority of the Framers of the Constitution: Can Originalist Interpretation Be Justified?
}

\author{
Larry G. Simon†
}

My ambition in this paper is to establish that the intent of the framers, drafters, and adopters of the Constitution is not an authoritative source for discovering the Constitution's meaning. Consequently, I will show that it is usually a mistake to beheve that in interpreting the Constitution, the Supreme Court inust, or at least sliould, refer to the meanings that constitutional provisions liad in the "original understanding." The group of clamis proinoting the use of the framers' intent in interpreting the Constitution is called originalism. ${ }^{1}$ While the Supreme Court lias paid originalism scant attention over at least the past lialf century, and while relatively few people probably subscribe to it, originalist criticism of Supreme Court beliavior lias persisted over the years, and has never been fully evaluated. ${ }^{2}$

The originalist critique of constitutional law is not a modest one, for it argues that almost all the constitutional decisions of the Supreme Court have been improper. ${ }^{3}$ For example, some originalists argue that none of the provisions of the Bill of Riglits sliould apply to the states, ${ }^{4}$ and that inany Bill of Riglits provisions sliould be interpreted more narrowly than they are today. The free speech clause should only bind Congress, and slould prevent it only froin estabhishing a licensing system for the press, and perliaps from criminalizing what the common law called

$\dagger$ H.W. Armstrong Professor of Constitutional Law, University of Southern California. B.A. i963, Hobart College; LL.B. 1966, Yale Law School. (1980).

1. Brest, The Misconceived Quest for the Original Understanding, 60 B.U.L. REv. 204, 204

2. For discussions advocating the originalist methodology of constitutional interpretation, see R. BERger, Government by Judiciary: The TRANSFormation OF THE FourteEnTH AMENDMENT (1977); Monaghan, Our Perfect Constitution, 56 N.Y.U. L. Rev. 353 (1981); see also A. Bickel, THE LEAST DANGerous Branch (1962); Bickel, The Original Understanding and the Segregation Decision, 69 HARV. L. REV. 1 (1955).

3. For a discussion of the changes in existing constitutional doctrine that would be required by originalisn, see Grey, Do We Have an Unwritten Constitution?, 27 STAN. L. REV. 703, 710-14 (1975).

4. The only way for an originalist to avoid this conciusion is to believe what Professor Grey has aptly called the "flinisy" historical evidence that the framers of the fourteenth amendment intended to apply the Bill of Rights to the states. Id. at 711-12 \& n.37. 
seditious hibel of government. 5 The fourteenth amendment should not be interpreted to outlaw racial segregation, to provide special protections to any group other than blacks, or to make equality questions relevant to the distribution of important rights, like the right to vote. ${ }^{6}$ The federal government should not be bound by norms preventing denials of equal protection or impairments of contract. ${ }^{7}$ The impairments clause should be more restrictive of the power of state legislatures to interfere with contractual expectations. ${ }^{8}$ The Constitution should not be interpreted to protect any right as "fundamental" uuless it is specifically embodied in the text or was part of the original understanding. ${ }^{9}$ Indeed, originahsm leads to a picture of a Court run amok, widely and wildly exercising illegitimate power.

In this paper, I am concerned both with "classical"10 originalism, and with the inore abstract concepts of original intention. My goal is to show that the original intention, conceived either concretely or abstractly, is not an authoritative source of constitutional meaning.

The argument for originalism rests at least implicitly on three claims. First, it argues that the framers and drafters of the original Constitution and its amendments shared a collective state of mind, called the framers' intent, and that this state of mind somehow reveals the meanings that these people as a group intended various constitutional provi-

5. Zechariah Chafee Jr. argued that the framers of the first amendment intended to bar the federal government both from hicensing the press and from criminalizing nominciteful seditious hibel of government. Z. Chafee, Free SPEech IN THE UNITED STATES (1941). Leonard Levy countered by denyimg that the framers intended to bar seditious hibel. L. LEVY, LEGACY OF SUPPRESSION (1960). In the early twentieth century, Justice Holmes, speaking for the Supreme Court, announced that the "main purpose" of the free speech clause was "to prevent all such previous restraints upon publications as had been practiced by other governments." Patterson v. Colorado, 205 U.S. 454, 462 (1907) (quoting Commonwealth v. Blanding, 20 Mass. (3 Pick.) 304, 313-14 (1826) and Respublica v. Oswald, 1 Dall. 319, 325 ( $\mathrm{Pa} .1788)$ ).

6. See Grey, supra note 3, at 712. See generally Bickel, supra note 2.

7. Grey, supra note 3 , at 711 \& n.36.

8. The impairments clause was not intended to apply to the federal government. Barron v. Mayor of Baltimore, 32 U.S. (7 Pet.) 242 (1833); Trustees of Dartmouth College v. Woodward, 17 U.S. (4 Wheat.) 518 (1819). The only way around this conclusion is to argue that the Court could read the fifth amendment's taking clause to include a ban against contract impairment. $C$. Umited States Trust Co. v. New Jersey, 431 U.S. 1, 19 n.16 (1977) (Contractual rights may be taken for public purpose if compensation is paid).

9. This implication is obviously definitional to originahism.

10. Classical originalism is the position currently espoused most vigorously by Professor Berger. See, e.g., R. BERGER, supra note 2. Berger concludes that "[t]o 'interpret' the [Fourteenth] Amendment in diametrical opposition to [the framers'] imtention is to rewrite the Constitution." $R$. BERGER, supra note 2, at 407 . He argues that the framers had quite specific, himited, historieally and contextually identifiable goals and examples in mind, and that these goals and exainples, along with the text's clear meaning, should govern modern constitutional interpretation. Id. at 2-3. When I use the term "originalism" or "the original understanding" without making clear that I ain referring to more abstract concepts, I am using it to mean this type of specific or concrete intention. 
sions to have. ${ }^{11}$ Second, it claims that judges can come to reasonably reliable understandings about this state of mind by following the plain language of a provision and by researching the proceedings and/or the legal and social context surrounding a provision's adoption. ${ }^{12}$ Third, it posits that the ineanings supplied by the plain language and the research mto the originators' state of mind are, or ought to be, authoritative. ${ }^{13}$

A debate has raged during the past few years between originalists and their opponents over the first and second of these claims. ${ }^{14}$ Originalists have also debated among theinselves about the proper level of generality at which intentions sliould be identified. ${ }^{15}$ This paper deals by and large with the third claim, the authoritativeness of originalism, a subject that few besides Professor Brest have explicitly addressed. ${ }^{16}$

Originalist writings suggest three types of arguments might support their claim that the framers' intent sliould be controlling. The first is based on the nature of constitutionalism, the second on the nature of democracy, and the third on wliat are sometimes called tlie "rule of law virtues."

As a claim about constitutionahism, originalism can be articulated in two quite distinct ways. First, it might be claimed tliat it is implicit in the concept of a written constitution (or at least ours) that the original understanding provides the authoritative source of constitutional meaning, and that this meaning can be authoritatively changed only by amending the Constitution through the processes that are tliemselves set out in the document. This claim rests not on any independent reasons, but on the assertion that the exclusive authoritativeness of the original understanding is a first principle not in need of justification.

The second defense of originalisin as a claim about constitutionalism argues that there is sometling normatively special about tlie role, status, or institutions of the origination. This claim seens to be based on con-

11. See, e.g., R. BERGER, supra note 2. For criticisms of this notion, see Brest, supra note 1; Dworkin, The Forum of Principle, 56 N.Y.U. L. REv. 469 (1981).

12. See Monaghan, supra note 2, at 377. See generally R. BERGER, supra note 2.

13. Madison said that if "the sense in which the Constitution was accepted and ratified by the Nation . . . be not the guide in expounding it, there can be no security for a consistent and stable [government], more than for a faithful exercise of its powers." R. BERGER, supra note 2 at 3 (quoting 9 J. Madison, The Writings of James Madison 191 (G. Hunt ed. 1900-10)). See generally $\mathrm{R}$. BERGER, supra note 2, at 1-3, 363-72.

14. See, e.g., R. BERGER, supra note 2, at 6-7, 368-69; Bennett, Objectivity in Constitutional Law, 132 U. PA. L. Rev. 445, 459 (1984); Bork, Neutral Principles and Some First Amendment Problems, 47 IND. L.J. 1, 13, 17 (1971); Brest, supra note 1, at 212-13; Dworkin, supra note 11, at 476-82. I have outlined these debates in another paper. See Simon, The Authority of the Constitution and Its Meaning, 58 S. CAL. L. REv. 603 (1985).

15. Bennett, supra note 14, at 461-65; Brest, supra note 1, at 212; Dworkin, supra note 11, at 482-88.

16. For Professor Brest's discussion of the authoritativeness of originalism, see Brest, supra note 1 , at $224-38$. 
tractarian conceptualizations of the Constitution, and depends explicitly or implicitly on the justifications for regarding plain ineaning or intent as the source of neaning in contract interpretation. These conceptualizations, in turn, may be based either on social or real contract concepts. Social contract conceptions might support the claim that originalism is the exclusive source of meaning of all constitutional provisions, while real contract conceptions might support either this claim or a lesser one on behalf of some constitutional provisions.

Alternatively, originalism might be defended as a claim about democracy. This claim argues that limitimg the meanings of constitutional provisions to those that existed at the time of their origination serves to confine the interpretive power of the Supreme Court, a power that some see as a threat to the proper functioning of democracy. An originalist position is based on democratic theory, in other words, to the extent it is derived from a vision about the proper relationship between the court and agencies of government that are theoretically responsible to the people. As a byproduct of theories about democracy, this position is not necessarily based on any claim about the special role, status, or institutions of the origination, or the affirmative virtues of originalist interpretation.

Finally, originalism might be defended on the basis of the rule of law virtues. It might be argued that originalism best promotes the virtues of certamty, predictability, and administrative efficiency. Claims like these might be true, if at all, for all or for only some constitutional provisions.

In this paper I evaluate originalism insofar as it is based on claims about, or visions of, constitutionalism or the rule of law virtues. I leave to another time more direct discussion of the relationship between democratic theory and judicial review, as well as any other "coincidental" defense of originahsm. I argue in Part I that originalism cannot simply be assumed to be an authoritative source of meaning, and that the only way to evaluate competing methods of constitutional interpretation is to ask which is better justified. Part II then outhines the intellectual enterprise of justifying a method of constitutional interpretation. In Part III, I show that neither of two social or real contract conceptions can provide a persuasive justification of originalisin.

I argue in Part IV that abstract intention theories cannot simultaneously cure the injustice of concrete originalism and provide a contractarian justification for themselves. In this regard, I suggest that Professor Rawls's social contract theory of justice and Professor Dworkin's abstract originalist theory are not really originalist in any meaningful sense, and consequently that the justification of both must come from someplace other than the real or hypothetical "consent" of the real or hypothetical originators. Part $\mathrm{V}$ shows that while the rule of law virtues 
occasionally can justify originalist interpretation, the occasions are identifiable and fairly rare, given all of the values that do and ought to bear upon constitutional interpretation. I then speculate in Part VI on some of the broader imphications of iny conclusions for the evaluation of past Court behavior and the institution of judicial review today.

\section{I}

\section{AUTHORITY, JUSTIFICATION, AND INTERPRETATION}

I begin by providing a brief explanation of several concepts that appear throughout, and that I have discussed at greater length elsewhere. ${ }^{17}$ A text is "legally authoritative" if it is regarded by the coininunity to which it apphies as a source of legally controlling norms. "Justification" is either the process of giving reasons or the substantive reasons given to support moral and legal claims. "Interpretation" is either the process by which people find meaning in a text, or the ineaning so found.

A text, a inethodology for imterpreting a text, or even a particular interpretation of a text inay be legally authoritative whether or not its authoritativeness can be justified. It does not follow, however, that questions of justification are irrelevant to the authoritativeness of texts, methodologies, or interpretations. The question of whether reasons can be given for regarding a text, nrethodology, or interpretation as legally authoritative is often relevant and soinetimes critical to understanding why it is accepted by society.

\section{A. The Authoritativeness of the Constitution and Originalism}

Justification may be neither necessary nor sufficient to establish the authoritativeness of a text, interpretive methodology, or particular interpretation. If everyone, or at least everyone who counts, regards a text as a source of controlling norms and regards as controlling or correct an interpretive methodology or a particular imterpretation of the text, then they simply are authoritative. In this situation, no reasons are necessary. In fact, if the attitude has been deeply internalized, the question of justification may not even occur to anyone.

The United States Constitution is authoritative, because major American institutional actors (e.g., legislative bodies, courts, and agencies) and a large seginent of the population have the appropriate attitude-that is, they regard the Constitution as a source of legally controlling rules and norms. Justification of the authoritativeness of the Constitution is therefore not necessary at present.

On the other hand, there is no widespread attitude about the proper

17. The argument in this section is more fully developed in Simon, supra note 14, at 609-19. 
method of constitutional interpretation. With regard to originalism in particular, the notion that the Constitution means wliat it meant in 1789 has liad virtually no currency in the Supreme Court during most of this century. Moreover, it is not taken seriously by any but a liandful of constitutional scholars, or, so far as I can tell, by the vast majority of the legally trained population. Furtlerınore, it seems implausible to think that there is any consensus among the American people at large that ties their regard for the Constitution to a set of meanings tliat existed in 1789.

Because there is no consensual or noncontroversial interpretive metlodology, the questions about which methodology and which imterpretations are proper cannot be determined by simply asserting that it is somehow "definitional" or "intrinsic" to a constitution that it be imterpreted $^{18} \mathrm{im}$ any particular way. The only people likely to accept such an answer are those who already beheve it.

Simce originalists cannot sinply assert their conclusions, they must provide some other, independent justifications for their proposed methodologies that are more persuasive than those advanced by other theorists. At a lieuristic level, the basic criterion for evaluating the arguments supporting the various methodologies or interpretations is the extent to which those metlodologies and interpretations promote a good and just society.

While these conclusions are in some sense obvious, it is worth restating thein in slightly altered form to emphasize tlreir innportance. There is no intrinsically "legal" or "constitutional" answer to the question how the Constitution should be interpreted. The evaluative standards must come from the external perspectives of political and inoral theory. Claims on behalf of the "authoritativeness" of competing constitutional interpretive metlodologies or interpretations therefore rest ultimately upon the authority of moral reasoning-that is, each argument claims that it is "autloritative" because (and only because) it is "correct" as a inatter of poltical inorality. Given the range of legitimate disagreement about the requirements of political morality, the "correct" or "authoritative" interpretation will often depend on the interpreter.

\section{B. The Source of the Constitution's Authority}

The conclusions outlined above require some additional attention, although a full development is neither necessary nor appropriate to this paper. These conclusions ultimately rest on an affirmative argument that the source or basis of the Constitution's authority is a shared attitude about certain norms of political morality. This attitude miglit be

18. I assume that "interpret" describes what the Court does when it applies the Constitution to the facts of cases. See Simon, supra note 14 , at 620 n.16. 
described either as a shared moral consciousness or identity, or as a deeply layered and shared consensus. Furthermore, the norms are understood by a sizable number of our citizens as representative of the value and importance of the Constitution.

The consciousness, identity, or consensual attitude consists of two interdependent and mutually reinforcing elements: paradigmatic examples of historically important episodes of our national moral life, and a widespread, though certainly not unanimous, socialized behief in several abstract values, such as democracy, freedom, equality, and justice.

It should not be surprising that these values-which I summarize and sometimes refer to either as the authority of goodness and justice, or more simply, of moral reasoning -have in fact greatly influenced judicial interpretations of the Constitution. At least im modern times, the courts have been more swayed in constitutional interpretation by arguments about what is good and just than by any other kind of arguments. ${ }^{19}$ Moreover, it is unlikely that a sizable segment of the American population would object to judges being guided mainly by what is good and just in interpreting the Constitution, although people certainly would disagree about which particular interpretations correspond to these values. ${ }^{20}$

The abstract values represented by the words "democracy," "free-

19. This is true both of major historical decisions and of more ordinary constitutional cases. For example, the Court was guided by its sense of justice or welfare and not by originalism, history, or precedent in reaching its decisions in Brown v. Board of Educ., 347 U.S. 483 (1954), and Roe v. Wade, 410 U.S. 113 (1973). It is this characteristic of these decisions that has brought them both praise and damnation. Compare P. MURPHY, ThE Constitution IN CRISIS TIMEs 312 (1972) (arguing that Chief Justice Warren was willing to "interpret the Fourteenth Amendinent in line, not with precedent, but with what experts had convinced the Court was the historic intention of its framers.") with Ely, The Wages of Crying Wolf: $A$ Comment on Roe v. Wade, 82 YALE L.J. 920 (1973) (condemning $R o e$ for failing to trace protected rights to Constitution). Even in routine constitutional cases, the Court's opinions are heavily supported by arguments about goodness and justice. This will be so, for example, in any case in which the Court "balances" (in one form or another) a constitutional value against a state justificatory interest.

20. Cf. Sinıon, supra note 14, at $615 \mathrm{n} .9$ (Americans share broad consensus about fundainental values, but consensus declines with specific application of those values). The fact that members of a soeiety regard some action as justified, however, does not mean that the act "really" is justified. Furthermore, even if many members of our society think it justified that in matters of constitutional interpretation judges are guided mainly by what is good and just, does it follow that the practice is "really" justified? The answer must be no, unless there exists a justification for the proposition that the people's beliefs in the concepts of goodness and justice ought to be given supreme legal expression. This justification requires an argument or political theory that persuasively defends this type of institutional arrangeinent. I hope to make such an argument at another time, but it is not necessary for present purposes.

The eventual argunent will necessarily discuss what is good and just for persons and society, i.e., the implications of our valuing democracy, freedom, equality, and justice. All I ain trying to establish at this tine is that in arguing about constitutional interpretation, "goodness" and "justice" are exactly what we ought to be, and the only thing we could coherently be, arguing about.

In my opinion, no "objective truth" stands behind justification. As Richard Rorty aptly observed, "objective truth' is no more and no less than the best idea we currently have about how to explain what is going on .... [It is] just the facts about what a given society, or profession, or 
dom," "equality," and "justice" and the paradigmatic stories that embody them are not self-defining. Given the range of past and potential interpretations of the terms, these values make relevant to the evaluation of competing interpretive methodologies and particular interpretations all of the moral concepts in our culture. Given the competing and often conflictimg values involved, a system and theory of moral reasoming is needed to resolve the textual ambiguities and interpretational conflicts that inevitably arise.

The recogmition that the authority of the Constitution hies in moral reasoning leaves many difficult problems. It does not, for example, foreclose entirely the possibility that origmahism is the "best" interpretive inethodology. Moral reasoning does require, however, that the claims be inade and evaluated by reference to what is good and just for mdividuals and society. It therefore is a way to frame the argument, and raises the question of whether originalism can be justified through moral reasoning.

\section{II \\ THE INTELLECTUAL ENTERPRISE OF JUSTIFYING ORIGINALISM}

It seems useful before turning to the question whether originalism can be justified to sketch out some of the mam characteristics of such an enterprise. Four points are of sufficient importance to warrant brief prehminary attention. First, justification is accomphshed through moral reasoning and consists ultimately of appeals to what is good, right, or just. Though such reasoning is eclectic and often controversial, it has reasonably identifiable modes, and it serves a perhaps indispensable social function. Second, while the standards of both authoritativeness and justification are subject to historical change, a proposed method of interpretation must be justified by contenporary standards. Third, while moral claims or beliefs sometimes have procedural imphications, and while process is often important evidence in the evaluation of such claims, procedures are rarely if ever intrimsically valuable. Fourth, originalisin can only be justified by the provision of sound reasons to follow the original understanding precisely because it is the original understanding. An argument based on reasons of a different sort might support giving some provision of the Constitution a meaning that happens to correspond to the original understanding, but it caimot justify originalism.

other group, takes to be good ground for assertions of a certian sort." R. RORTY, PHILOSOPHY AND THE MIRROR OF NATURE 385 (1979). 


\section{A. Moral Reasoning}

"Moral reasoning," as the term is used in this Article, is an expansive concept. To fall within it, a claim need have no special conceptual or ontological character or pedigree. Any argument based on a clain that a course of behavior is good for persons or society, or that it is required by justice or fairness, is a moral argument. Moral argument encompasses, for example, arguments from social convention as well as "purer" or more learned forms of philosophical discourse, arguments based on economic analysis as well as what lawyers have come to call "policy arguments," and those based on radical or "prophetic" reinterpretations of social relations or values.

Moral reasoning follows from the concepts of goodness and justice and the way they function in society. We appeal to these concepts whenever we argue that something should or should not be done because it is good or bad, right or wrong, just or unjust. Of course, many methods of moral reasoning or argument exist, and the relationships among them are complex and confusing. For present purposes it suffices to organize them under the headings of welfare (or utility), justice (or fairness), and ideals (or virtues).

Welfare-based moral argument is grounded in the belief that an action is justified because it is "good" for people, in the sense that it adds to their welfare, happmess, or utility. Justice-based moral arguments attempt to identify what is just or fair from a point of view that is neutral with respect to different peoples' identities, imterests, ends, or conceptions of the good. Ideal-based moral arguments are grounded in the belief that an action is justified because it is good for people in other or additional ways. These "goods" tend to be associated with cultural values, shared aspirations, communal ideals or goals, and the idea that some wants or preferences are better than others. ${ }^{21}$

Of course, welfare, justice, and ideals may often in principle be incompatible. People will disagree over the criteria of goodness and justice, the relationship among various criteria, and the evaluation of particular actions. People who interpret claims identically and who even hold the same general criteria of goodness and justice may disagree over how these apply to particular actions. Those who hold different criteria or who attach different degrees of importance to the same ones obviously will often disagree.

21. The accuracy and comprehensiveness of this tripartite categorization of methods of moral reasoning is not central to our present task. The important point is the recognition of a widely employed system of reasoning, argument, and evaluation, which demonstrates that our society seems committed to the possibility of moral reasoning, argument, and justification. I use the categories because they allow us to consider moral argunients in a somewhat organized way, not because I am convinced they are right. 
The possibility of disagreement may eventually undermine a society's commitment to moral reasoning and impair or destroy whatever social functions moral reasoning performs. The current commitment is nonetheless reflected in the belief, apparently widely held, in the concepts of goodness and justice-the belief that in both planning and justifying actions, it counts in favor of doing or reframing from doing something that the act is good or bad, right or wrong, fair or unfair. If a society's behief in, and resulting commitment to, moral argument were sufficiently undermined, presumably inoral reasoning, at least in its current form, might even cease to exist.

It is not easy, however, to imagine a world devoid of inoral reasoning. Except for the narrowest sort of utilitarian appeals to self-interest, arguinent would be impossible. Whatever deeper functions it may perform, ${ }^{22}$ moral reasoning makes possible many forms of persuasive and justificatory commumication. Appeals cast in the form of a inoral argument do not rest blatantly on the self-interest of the speaker. They therefore provide some basis for arguinent other than the relative worth of the arguers. As Alasdair MacIntyre lias said, "I disapprove of this; do so as well!' does not have the same force as saying 'That is bad.! "23

\section{B. Authority, Justification, and History}

The fact that the framers' intent is not the authoritative method of interpretation for our society does not mean that it was not authoritative for earlier societies. The authoritativeness of a method of constitutional interpretation can change througl listory. Thus, while the relevant inembers of modern society may not take an attitude towards the framers' intended meanings for constitutional provisions, the relevant members of a past society may well have done so.

For example, the relevant inembers of the framers' society may have regarded the Constitution as a bargained-for social contract, through which the framers as representatives of all relevant interests reached an agreement which improved at least some peoples' welfare and left virtually no one worse off than before. ${ }^{24}$ If so, a particular version of framers' intent may have seemed the logical or necessary reference point for disagreements about the text's meaning, since it may have seemed the obvious touchstone for determining the scope and content of the assumed bargain they had reaclied. ${ }^{25}$

22. An optimistic appraisal of moral argument holds that it guides judgment by the accumulated msight of experience or tradition; a pessimistic one argues that it disguises the dominance of some groups or classes over others. See also infra note 66.

23. A. Macintyre, After Virtue 19 (1981).

24. See infra text accompanying notes $36-42$.

25. See infra text accompanying note 42 . 
Conversely, the fact that framers' intent may have been regarded as both the authoritative and justified method of interpretation in earlier eras does not make it so today. The authoritativeness of framers' intent depends on the attitudes towards it among relevant members of contemporary society, and these attitudes may change with time. As these changes occur, the society must decide how past justifications have been affected and must choose a new method of interpretation if it decides the previous methodology no longer rests on sound moral footing. Each society must choose its own method of interpretation on the basis of its own standards of justification.

\section{C. "Procedural" and "Substantive" Justification}

At least as a matter of conceptual possibility, originalism might be justified by purely "procedural" considerations. We are all familiar with the frequent and much-criticized claim that courts should show constitutional deference to legislation merely because the "democratic process" generated it. ${ }^{26}$ Comparable claims might presumably be made about the relationship between the processes through which the Constitution was adopted, on the one hand, and its authority and meaning, on the other.

No useful function, however, is served by distmguishing between "procedural" and "substantive" justifications insofar as originalisin is concerned. As others have argued in connection with the more familiar debate over judicial role and democratic process, substance and process are exceedingly difficult to disentangle. ${ }^{27}$ Describing a procedure as "democratic" is both descriptively and normatively vague, and atteinpts to isolate descriptive characteristics that define democratic procedures have not been very successful. ${ }^{28}$ Furthermore, most people probably do

26. This theme has been central to constitutional law at least since the Supreme Court's confrontation with President Roosevelt in the 1930's. The Court's best known discussion of this subject is probably in footnote four of United States v. Carolene Prods. Co., 304 U.S. 144, 152-53 (1938). The most well-known recent attempt to elaborate a constitutional theory on this basis is $J$. Ely, Democracy AND Distrust (1980).

27. See, e.g., Brest, The Substance of Process, 42 OHIo ST. L.J. 131 (1981); Tribe, The Puzzling Persistence of Process-Based Constitutional Theories, 89 YALE L.J. 1063 (1980).

28. For an introduction to the problems of defining democracy, sec H. MAYo, AN INTRODUCTION TO DEMOCRATIC THEORY 21-34 (1960). Some theorists havc argued, persuasively in my view, that "democracy" is necessarily a normative as well as a descriptive concept. See Miller, Linguistic Philosophy and Political Theory, in The Nature of Political Theory 35 (D. Miller \& L. Siedentop eds. 1983). Nonetheless, some continue to attempt procedural definitions. A recent and imtelligent effort can be found in R. DAHL, DILEMMAS OF PlURALIST DEMOCRACY 5-6 (1982). Dahl lists five "ideal" procedural criteria he claims are preconditions to democracy as a deseriptive concept: equality in voting, effective participation, enlightened understanding, final control over the agenda, and inclusion. Dahl recognizes that a systein satisfying all five criteria would not necessarily be a "good" polity, id. at 7, and that it could not satisfy someone who believed that democracy is intrinsically a normative (and therefore controversial) concept. Moreover, Dahl's supposedly "procedural" criteria are themselves based on inplicit "substantive" moral theories. For example, is 
not value "democracy" simply because of the processes that constitute it. $^{29}$. More likely, people value what they think of as democratic procedures because they believe those procedures lead to good or just outcomes.

This is not to say that what is important is "substance" and not "procedure," but rather that it is difficult to sort the two out in any sensible and useful fashion. Consider, for example, Professor Rawls's category of "pure procedural justice." This category of justice "obtains when there is no independent criterion for the right result: instead there is a correct or fair procedure such that the outcome is likewise correct or fair, whatever it is, provided that the procedure has been properly followed." 30 His example is gambling, and his claim is that "[i]f a number of persons engage in a series of fair bets, the distribution of cash after the last bet is fair, or at least not unfair, whatever this distribution is."31

I understand Rawls to say that the fairness of an outcome may depend entirely on whether certain procedures were followed. I think he is not saymg that selecting the criteria of fair procedures presents purely a "procedural" as opposed to a "substantive" question, and if he is, I think he is quite clearly imstaken. The fairness of procedures cannot be determined without reference to the game or system which they constitute or serve. Using loaded dice is unfair because this form of gambling should depend on random chance. Thus a "substantive" judgment supphes the criteria of fair procedures that in turn, when followed, generate a definitionally fair or just outcome. ${ }^{32}$

Widespread agreement does not exist on the substantive theory thought to justify democratic procedures. Notions of utilitarianism, however, pervade inuch of the discussion, the underlying behef bemg that decisions made through the democratic processes are most likely to increase the aggregate and average happiness in society. The point, however, is not whether the utilitariamist claim is true, but that the justification is inextricably colmected to at least the minimal "procedural

there a purely procedural justification for equality in voting? Finally, Dahl himself realizes that under a literal application of his criteria, no political system in the world is a democracy.

29. For a review of the major theories of democracy's value, see W. NELSON, ON JUSTIFYING DEMOCRACY (1980).

30. J. RAWLS, A THEORY OF JUSTICE 86 (1971).

31. Id.

32. Professor Barry makes this point succinctly in discussing the rules of racing. "Whatever it is that the race is supposed to be testing, it is hard to see how its reliability would be improved if some competitors got away with jumping the gun, except in the perverse case where the race is a blind and the real test is in gun-jumping abihity." B. BARRY, Polmtical ARgument 103 (1965). I can think of only one case in which we properly might speak of pure procedural justice, and this is when we can agree on no goal to be pursued but some deeision process is necessary and we can agree on such a process. The allocation of scarce lifesaving equipment by lottery might be such an example. 
condition" of a causal relationship between the welfare of the people and the acts of the government. ${ }^{33}$ In other words, making governmental decisions without regard to the peoples' welfare is "unfair" or "bad" at least $\mathrm{m}$ part because the point of democratic government is to maximize social welfare.

The justification of democratic procedures could also rest on notions of personal rights, such as freedom of speech. It seems at least presumptively obvious, however, that the principal criterion for the evaluation of both democratic procedures and the laws that are their outputs must come from substantive moral and political values. ${ }^{34}$

This does not mean that process is unimportant. Very often, for example, the best evidence of the extent to which a decision might enhance public welfare is the process that generated it. This Article, therefore, often talks about process, but does not rest on the claim that processes are valuable intrinsically, and does not conceptualize procedural fairness, goodness, or justice as a separate category of justification.

\section{Originalist-Coincidental Arguments and Their Implications}

Justifications that lead to interpretations of the Constitution identical to those of the originalists but which are based on values that are independent of and provide no affirmative reasons for originalism are originalist-coincidental. Depending on their value bases, these are either not justifications for originalism at all or are justification by residualism, in that their force depends not so much on the positive value of originalisin as on the lack of better alternatives.

Originalism also is not justified by an argument that the framers' intentions should be followed because the values they sought to proinote are the "right" ones-that the implementation of these values promotes a good and just society. If successful, this argument would justify giving the Constitution originalist meaning, but by virtue of the fact that the framers' values happen to be good and just today, not because they are originalist values. In other words, if arguments supporting originalism focus on the goodness and justice of originahist interpretations, then the resolution of the question of constitutional methodology will depend entirely on judginents about which interpretation produces greater good

33. The conditions may even be stronger, and may require that the people whose welfare is at issue be able to select their government.

34. For just this conclusion as well as a nonencouraging evaluation of the utilitarian case for democracy, see J. Pennock, Democratic Political Theory 3-15 (1979); see also W. Nelson, supra note 29 , at $72-93$.

The implications of this analysis upon the relationship between democratic theory and judicial review are the topic of a future paper. For now, it suffices to say that I very much doubt whether the Constitution's authority and/or any methodology for interpreting it can be justified by "purely procedural" arguments about the process of its adoption or amendment. 
or justice. The argument over interpretive inethodology therefore collapses into an argument over the merits of the respective interpretations.

Perhaps the inost important originalist-coincidental arguinent is based on democratic theory. The argument claims that any less restrictive method of interpretation poses an unacceptable threat to electorally responsible institutions, and therefore allegedly poses an unacceptable threat to democracy. ${ }^{35}$ To the extent that proponents of this arguinent arrive at originalisin as the proper method of interpretation not because of its virtues but because of the vices of other methods of interpretation, they are engaging in the residualist form of originalist justification. This topic, however, falls under the heading of democratic, not originalist theory, and is beyond the scope of this Article.

\section{III \\ CONSENSUALIST TRADITION}

Conceiving of the Constitution's authority as based on consent is not the only way to justify originalism, but it seems to be the most popular. ${ }^{36}$ There are two main consent-based conceptions of the Constitution. The first is contractarian, and proposes to view the Constitution as a negotiated contract. The second regards the Constitution as an embodiment of deeply layered and shared consensual attitudes toward certam paradigins and norms of political morality. ${ }^{37}$

Neither conception can justify originalism. The first fails because the original bargain was struck by a group not representative of the diversity of interests and values im its or m our own society. It also fails because, viewing the originators as self-interested bargainers, it is unrealistic to suppose that they believed their interests extended into the then far distant future. The second fails because there are strong reasons to beheve that any deep consensus that inay exist today over fundamental

35. Cf. R. BERGER, supra note 2, at 4-5. "The Court has shown in the past that the Constitution can also be twisted to frustrate the needs of democracy." Id.

36. See generally Friedrich, Constitutions and Constitutionalism, in 3 INTERNATIONAL ENCYClOPEDIA OF THE SOCIAl SCIENCes 318 (1968); Grey, Constitutionalism: An Analytic Framework, in 20 Nomos: CoNSTITUTIONALISM 189 (1979).

37. The two consent-based conceptions of the Constitution considered in the text are not the only "social-contract interpretations." In fact, the inost cominon conception of the social contract is based on hypothetical consent, and not on the concept of real consent at all. As William Nelson puts it: "the idea of focusing on what could be agreed to or on what could constitute a consensus is hike the idea that seems to underlie much moral theory in the social contract tradition." W. NELSON, supra note 29, at 104 (1980) (citation omitted). Based on this interpretation, Kant, Rousseau, and Rawls are all social-contract theorists. See Ryan, Mill and Rousseau: Utility and Rights, in Democratic Theory and Practice 39, 55 (G. Duncan ed. 1983).

The relationship between originalism and these social-contract theories are discussed infra at text accoinpanying notes 63-69. It is open to serious question whether anything is gained by clothing such political theories in the language of "contract." 
values and inay justify treating the Constitution as law does not correspond with the concrete intentions of the originators.

\section{A. The Constitution as a Bargained Social Contract}

\section{Exclusive Originalism}

People often seem to regard the Constitution as a "social contract." Some writers have suggested that the considerations that support interpreting contracts to mean what the contracting parties intended also support exclusively-originalist interpretations of the Constitution..$^{38}$

The conceptualization of the Constitution as a contract has been of inore than theoretical importance in American history. Professor Powell recently has shown that a conception of the document as a contract among sovereign states was the imphicit and original basis of the arguinent for its "strict construction." This argument, in turn, provided the legal foundation for several actions by state legislatures purporting to nullify federal law and jurisdiction, such as the 1798 Virginia and Kentucky resolutions denouncing as unconstitutional the Federal Alien and Sedition Acts. ${ }^{39}$

Whether those claims for strict construction can be justified depends on whether the underlying conception of sovereignty can be justified, a question which Professor Powell concludes strict constructionists begged by "justifying substance by a mode of interpretation justified only by that same substance."40 The basic question of justification, 1noreover, raises issues $\mathrm{m}$ pohtical and moral theory far more bewildering than those raised by "normal" contracts, since its "answer" turns on the relative justifiability of claims that an inclusive or an included group of people constitutes a nation-state. Judging from history, including our own, disputes like these are more likely to be settled by war than by moral reasoning. While moral and pohtical arguments are relevant, they seein unlikely to provide a vehicle for such a dispute's resolution in a political culture polarized by strong interest-based disagreements over these kinds of ultimate questions.

In any event, the analogy to contract is quite inisleading. A private contract may be widely beheved to constitute an authoritative ordering of the relationship between the contracting parties with respect to the inatters it encompasses. To the extent this is true, a private contract is authoritative, much like the Constitution. The problem is that a private contract's authoritativeness has hittle to do with its meaning. To under-

38. See, e.g.. B. Siegan, Economic Liberties and the Constirtution 13 (1980).

39. Powell, The Original Understanding of Original Intent, 98 HARv. L. REV. 885, 924-25, 944-47 (1985). This argument for strict construction was ultimately rooted in eighteenth century conceptions of sovereignty, not in the intention of the originators. Id. at 931 .

40. Id. at 934 . 
stand how to resolve ambiguities in the ineaning of such a contract, a judge inust do just what I have suggested be done with the Constitution: he or she must inquire into the values and attitudes that provide the basis for people's belief in the authority of the agreement in question.

Most likely, contracts are valued and regarded as authoritative because they allow autonoinous, welfare-enhancing social ordering. ${ }^{41}$ These autonomy and welfare values justify interpreting a contract to mean what its autliors intended. If each person is the exclusively legitimate source of authority over his or her own behavior, unanimous agreements sucli as contracts carry the cumulative authority of eacli of its sovereigu, autonomous signatories. Furthermore, if contracting parties are rational agents, they may safely be assumed to have contracted so as to increase their welfare above the baseline froin which bargaining cominenced. The resulting contract is justified precisely because it represents an increase in aggregate happmess, and at least no decrease in any individual's happiness. ${ }^{42}$

Under this theory, the proper source of meaning would be the contracting parties' states of mind or the reasonable interpretation of eacl1 party's state of mind. Both the autonoiny and the utility justifications make critically important the contracting parties' understanding of the contents of their agreement and the interests that agreenent either benefits, or at least does not harm.

Neither institutions for the creation of contracts nor the contracts themselves, however, can be fully justified on either autonomy or utility grounds without inquiring into the justness of the positions froin which bargaining commenced. ${ }^{43}$ We can avoid these problems, not because they are unimportant, but because there are other inore obvious and

41. Cf. A. SchwartZ \& R. SCOTT, Commercial Transactions 18-27 (1982) (Commercial Code should be interpreted either to resolve disputes as parties would have done had explicit bargaining taken place, or to allocate loss to cheapest cost-avoider if parties are ignorant of each other's existence). For an interesting discussion of some of the underlying issues, see Colennan, Efficiency, Utility, and Wealth Maximization, 8 HoFsTRA L. REv. 509 (1980).

42. This "no lose" situation is often described as "pareto superior" to the preexisting state of affairs.

43. See Bebchuk, The Pursuit of a Bigger Pie: Can Everyone Expect a Bigger Slice?, 8 HoFsTRA L. REV. 671, 688-709 (1980). Similarly, even if everyone in the nation had fully participated in the Constitution's adoption and agreed that the document, given the original understanding, truly improved their welfare, the Constitution still would not necessarily be just. The reason is that many of these people might have taken a different view if they had the greater status, education, and wealth that they "ought" to have had according to contemporary inoral standards.

This possible distributional injustice thus undermines the welfare-based justification for binding people to the contract, because the welfare justification does not address questions of justice. Welfare-based justification therefore works only if the baseline is assumed to be just, or if it was in fact just, or if justice does not inatter.

The possible distributional injustice also undermines the autonomy-based justification for binding people to the contract. The concept of "autonomy" presupposes that some apparent exercises of the will amount to "free choice" and that some do not. It is simply not clear whether or 
clearly fatal difficulties with deploying either the autonomy or Pareto version of consent theory to justify the process through which our Constitution was adopted.

These problems are embarrassingly obvious. The Constitution received far from overwhelming consent even from those who participated or were eligible to participate, much less from the eighty percent of the population that was imeligible. ${ }^{44}$ The autonomy and Pareto values that underhe consent theory simply calmot justify binding the dissenters or the disenfranchised (let alone later generations) to the will of the chique that prevailed.

The argument that one day's losers are another's winners, given the horse trading and shifting coalitions of American politics, ${ }^{45}$ is often used to support the fairness and utility of binding dissenters to legislation. The argument offers hittle consolation, however, when discussing the Constitution. The legal and political prerequisites to constitutional amendment are so restrictive that amendment is virtually a once-in-ahifetime possibility. The argument is inapplicable even as to enfranchised dissenters, much less the disenfranchised and their legatees in interest.

One possible response is that I am rejecting an overly theoretical version of social-contract theory. My argument might be read to imply that a constitution promotes autonomy and welfare values only if it

to what extent "choices" made by people "bargaining" with those who in some sense "dominate" them count as free choices.

Among the better known and more interestimg attempts to deal with this problem is Nozick, Coercion, in Philosophy, SCIEnCe ANd Method 440 (S. Morgenbesser, P. Suppes \& M. White eds. 1969). A variation of this same problem is also at the heart of the so-called "false consciousness" debate. See infra note 66.

44. It has been estimated that eighteen to nineteen percent of the population at that time were adult males, and that only eighty to eighty-five percent of this population was eligible to participate in ratification eleetions. R. Brown, Charles Beard and the Constitution: A Critical ANALYSIS OF "AN ECONOMIC INTERPRETATION OF THE CONSTITUTION" 69 (1956). Some historians claim that only twenty to twenty-five percent of those eligible actually participated. $L$. HACKER, THE SHAPING OF THE AMERICAN TRADITION 238 (1947). Of the roughly 160,000 adult males who voted, not more than 100,000 favored ratification. C. BEARD, AN ECONOMIC INTERPRETATION OF THE CONSTITUTION OF THE UNITED STATES 250 (1935); F. MCDONALD, We the People: The Economic Origins of the Constitution 14 \& n.11 (1958). The population of the nation in 1787 was approximately four million. C. RossiTER, 1787: THE GRAND CONVENTION 25 \& n.5 (1966) (citing U.S. Bureau of the Census, Historical Statistics of the United States 7-14 (1960)). In other words, roughly $2.5 \%$ of the population voted in favor of the Constitution's ratification.

Given this data, Professor Monaghan's assertion that "viewed in its historical setting" the constitution was "remarkably 'democratic" " strikes me as odd. Monaghan, supra note 2, at 395. Furthermore, contrary to Monaghan's assertion, the amendment process does not cure the democratic inadequacy, by current standards, of the origination. See infra Part III, Section $C$. In any event, whether it was democratic by late eighteenth-century standards is not, for our era, the important question. See supra Part II, Seetion $B$.

45. For citations to the major works on the role of logrolling in democatic theory, see Wilson, An Axiomatic Model of Logrolling, 59 AM. ECON. REv. 331, 331 (1969). 
receives unanimous approval. Any lesser majority allows the objections or dissent of some to be overridden. Originalists might then claim that unanimity is a preposterously demanding standard of justification for political action. Even conceding that no other voting rule fully protects dissenters, it is still better to have some such procedure for enacting legislation, lest the dissenters in effect control the rest of the group. Thus, it might be claimed that the Constitution can be fairly conceptualized and defended as a negotiated social contract, even though it did not receive unanimous consent.

With this claim I agree, but the social-contract theory I reject does not presuppose unanimity as a condition of justification. Requiring unanimous consent as a condition for the justification of pohtical action is objectionable for two reasons, even aside from its obvious impracticality. First, by allowing each affected individual to prevent collective action, such a requirement perpetuates whatever distribution of resources exists at the time the decision at issue is to be taken. This can be justified only if the distribution is just, or if justice does not matter. ${ }^{46}$

Second, a requirement of unanimous consent confers a veto power on individuals, allowing someone who clearly stands to benefit from the proposal at issue to refuse consent in order to extort an advantage over the others. Rewarding greedy people at the expense of everyone else is morally objectionable. Particularly when the decisionmaking group is very large, it also poses welfare problems, both because it will result in substantially higher lawmaking (or bargaining) costs than a less-thanunanimous voting rule, and because greedy individuals may miscalculate the social benefits of a proposed action and may demand too much, blocking a change that would have made everyone better off. ${ }^{47}$ Although it inay not be possible to know what voting rule would best promote autonomy and welfare value while minimizing the veto problem, it plamly is not the rule of unanimity. For these reasons, it is in principle not possible to justify a unanimous-consent requirement, and therefore it is foolish to believe that unanimity can be a condition for the justification of political action.

In any event, I can accept that the adoption of a constitution binding on everyone by a voting rule short of unanimity is justified. The problem with the United States Constitution, however, dwarfs this theoretical concern. The Constitution was adopted by propertied, white males who had no strong incentives to attend to the concerns and interests of the impoverished, the nonwhites, or noninales who were ahve then, much less those of us alive today who hold conceptions of our interests and selves very different from the ones held by those in the orig-

46. See supra note 43.

47. B. BARRY, supra note 32 , at $245-49$. 
inal clique. ${ }^{48}$ These are hardly small or overly theoretical problems for a theory that proposes to bind us to the chique's intent for reasons that, if coherent, inust ultimately be rooted in our own autonomy and welfare. They are thus fatal criticisms for any contract-based claim for originalism as the exclusive method of constitutional interpretation.

Even if we were to put aside all these objections, the conception of the Constitution as a bargained contract still cannot provide a persuasive justification for exclusive originalist interpretation. The affirmative argument for originalist methodology caves in upon analysis, for it rests on unrealistic and improven empirical assumptions.

The argument for exclusive originalism presumably proceeds as follows. The population of the original thirteen states, through the ratification process, consented to the agreement represented by the Constitution and its underlying intentions because a great many gained and few lost because of it. Interpreting the Constitution to mean something other than the contents of the original agreement creates meanings never approved by the people, and therefore impairs the choices of the "contracting" parties. These deviations from original intent thus transgress autonomy values, and will eventually decrease social welfare and produce societal instability.

But people do not generally lock themselves into practically unchangeable agreements that will bind not only themselves, but future generations as well. It seems considerably more likely that to the extent they viewed themselves as bargaining over a contract, the framers and originators of the Constitution were much more concerned about the present and the near future than about the twentieth century and beyond. ${ }^{49}$ This rather obvious conclusion is merely an observation about

48. The proponents of the Constitution have been described as those who felt most strongly the inadequacies of the Articles of Confederation-merchants, lawyers, and large landowners. P. SMith, The Constitution: A Documentary and Narrative History 86-87 (1978). The delegates (drafters) were selected by the legislatures of each state and were chosen without any formal electoral input. C. BEARD, supra note 44, at 71-72; F. MCDONALD, supra note 44, at 22-37. Virtually every state had property or income qualifications in order for a person to be a state legislator. R. BRown, supra note 44, at 62-66. Every state also effectively made property ownership a prerequisite to the right to vote, either by a direct property qualification or by denying the right to all but taxpayers. C. BEARD, supra note 44, at 65-77; 3 E. CHANNING, A History OF THE UNITED STATES 446 (1912); C. WARREN, THE MAKING OF THE CONSTIrUTION 399-403 (1928). Naturally, the franchise was himited to adult white males only.

49. Professor Powell's recent historical analysis suggests that these coinmonsense conclusions have some basis in historical reality. Professor Powell's main conclusions are that there was no consensus on the proper method of constitutional interpretation during and iminediately after the ratification process, Powell, supra note 39 , at 887 , that the consensus which emerged in the early nineteenth century was on a form of structural interpretation focused on the presuppositions of the

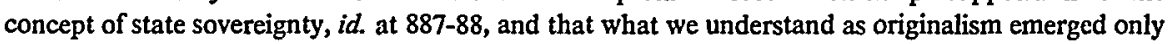
later, $i d$. at 888 .

Perhaps the clearest evidence of the early rejection of originalism is in the writings and official conduct of James Madison, who believed that the ineaning of the Constitution was to be found in 
the way most people operate. Certainly the originators understood that their interests were inuch more vitally at stake during their own lifetimes than thereafter. To the extent that this observation is true, the originators may be supposed at most to have reached a bargain calling for interpretation according to plain or intended meaning only for a relatively short period of time. The methodology that people of distant generations should use to interpret the Constitution simply was not part of the originators' self-interested bargain.

Moreover, it is not at all clear that the parties to the original agreeinent would have preferred strict adherence to plam and intended meaning of all constitutional provisions throughout their own lifetines. They inay have originally believed that the Constitution embodied their preferences but later changed their minds with respect to some provisions. Conditions and circumstances change with times, and what was once in a signatory's interest inay later prove detrimental. Sonne or all of the originators eventually might have been willing to consent to an interpretation different from plain or intended ineaning because it would yield greater welfare gains.

The answer to this question depends more on conjecture than political theory. For example, the originators' affection for the amendment process may have been partly based on the assumption that Constitutional amendment would have been fairly easy, given the relative homogeneity of those entitled to participate politically. Had they lived to observe economic growth and its consequential diversification of interests, as well as expanding immigration and mcreasing pressure for the extension of suffrage, the originators might have begun to realize that the amendinent process was hopelessly cumbersome. In this event, they might have welcoined nonoriginalist but welfare-enhancing court interpretations of the Constitution.

\section{Nonexclusive Originalism}

While the autonony and welfare values that underhe consent theory cannot justify originahism as the exclusive method of constitutional interpretation, they might justify originahst interpretation of particular provisions. This will be true for any constitutional provisions that, because of rehance and expectation values, reasonably can be conceived to be like most ordinary contracts between the public and private sectors, or

social usage, not original intentions. Id. at 938-39. For example, while a Congressman, Madison had opposed on constitutional grounds the establishment of the First Bank of the United States, but as President twenty years later, he signed into law the act creating the Second Bank. He justified his switch on the basis that the widespread use and acceptance of the First Bank by the people showed "a construction put on the Constitution by the nation, which, having made it, had the supreine right to declare its neaning." Id. at 940 \& n.287, citing and discussing Noveinber 1826 letter fron James Madison to Marquis de LaFayette. 
between two public authorities. Article VI of the Constitution contains a provision, for example, that, "All Debts contracted and Engageinents entered into, before the Adoption of this Constitution, shall be as valid against the United States under this Constitution, as under the Confederation."50 Constitutional provisions preventing federal, state, and local government fronı repudiating governmental contracts also fit this description to sonie extent. ${ }^{51}$ These provisions operate as a kind of general-entrenchment clause by virtue of which all governmental contracts for the jurisdiction cannot be changed merely by normal political action.

In the interpretation of these types of provisions, the courts arguably ought to resolve ambiguity by reference to the plain meaning and/or original intent. The argument for originahist methodology in these cases is based both on welfare and fairness considerations. Social welfare is probably increased by allowing governments to nake firm coinmitments to secure opportunities they might otherwise not have or to reduce the cost of otherwise available opportumities. Furthermore, defeating the well-founded expectations of a party who acted in reliance on particularized commitnients that were clearly part of the original understanding is unfair, at least to the extent that the party also believed that he had a firm commitment.

The presumptive appeal of the real-contract case for originalisn in instances like these does not extend to contemporary interpretation of the normal and historically troublesome provisions of the United States Constitution. We have seen that the strongest argunent for originalist interpretation under the conception of the Constitution as a bargained contract would arise during the lifetimes of the originators and the people hiving at the tine of the contracting. This is true because, when viewing the docunient as the product of self-interested trading, self-interest is most realistically implicated in the relatively short run. It is therefore difficult to beheve that even the certam knowledge of such a distant future interpretation would have materially affected the bargain or defeated any real rehance or expectation interests.

The near/distant future distinction is but one denionstration of the general proposition that the methodology of interpreting constitutional provisions caimot be regarded as presuniptively unchangeable. The seriousness of the threat to welfare or fairness values posed by a change in interpretive methodology presents an issue of fact, and calls for a judg-

50. U.S. CoNST. art. VI, cl. 1. Perhaps an even more striking example of "constitutional" entrenchment is the extent to which Great Britain's entry in the European Economic Community (the Common Market) will result in placing some issues beyond future Parliamentary control. See, eg., Sugarman, Britain and the European Economic Community, 10 TEX. INT'L L.J. 279, 311-20 (1975).

51. See, e.g., U.S. ConsT. art. I, § 10, cl. 1 ("No State shall . . pass any . . Law impairing the Obligation of Contracts . . . ."). 
ment mvolving the particular provision in question, the time at which the interpretive question arises, and the extent to which it is reasonable to suppose that the proposed change would have materially affected the bargain or defeated real rehance or expectations interests. Put differently, the question is whether a particular provision is a real contract, and it begs this question to assume that the answer is affirmative.

The subject and language of some provisions might make it reasonable to believe that interpretive deviations from originalism even far removed in time from the origination would negate material terms of the bargam or defeat real expectations. For example, given the express language of the debt-repayment provision in article VI, the likelihood that its inclusion was a inaterial inducement to the bargam, and the very focused and concrete expectations its inclusion would have created in creditors, the inere passage of time alone probably would not warrant an expectation-defeatimg interpretation. ${ }^{52}$ It is worth noting that debtrepayment schedules will rarely stretch so far into the future as to pose real problems like this, precisely because events in the distant future rarely have sufficient current value to be the subject of bargams. ${ }^{53}$

While it is conceptually possible to make a similar argument for applymg originahist methodology in interpreting provisions like the first amendment, or the equal protection and due process clauses, it seems extremely unlikely that inost deviations, even at times fairly close to the origination, would have negated inaterial terms of the bargain or defeated real rehiance or expectation interests. Suppose, for example, that in the Slaughter House Cases ${ }^{54}$ the Supreme Court had interpreted the fourteentli amendment to make the Bill of Rights applicable to the states, or in any event, to protect the right of butchers to practice their trade. I doubt that one could seriously inaintain that this nonoriginalist interpretation would have eitler negated the bargain that produced the fourteenth amendment or defeated real reliance or expectation interests created by its passage. Furthermore, any lingering doubts would be eliminated if the hypothetical Slaughter House judgment came in 1950.

The analogy to real contracts also fails with respect to many of the relatively unambiguous constitutional provisions. Suppose that in the early nineteenth century, the Court had interpreted the provisions requiring the President to be thirty-five years of age and natural-born ${ }^{55}$ to allow thirty-year-old naturalized citizens to assume the office. While there is a

52. This does not mean that an expectation-defeating interpretation could never be justified, but only that such a justification would require extraordinarily compelling and competing values. See infra text accompanying notes 136-49.

53. The present value of a promise to pay a sum in fifty years, inuch less two hundred, discounted at any realistic interest rate is near zero.

54. 83 U.S. (16 Wall.) 35 (1873).

55. U.S. CoNST. art. II, §1, cl. 5. 
substantial argument that such imterpretations would be improper, it is not based on any claimed negation of the original bargain, or on defeated reliance or expectation interests. It is simply not likely that anyone would have relied on these constitutional provisions or that the originators would have cared very inuch if anyone had.

The real-contract argument not only by and large fails to support originalism in constitutional law, but to the limited extent it inight be persuasive, it is subject to substantial counterclaims concerning what is good and just for society. Even in private-contract cases, courts will sometimes mvalidate contracts on public-pohcy grounds. ${ }^{56}$ Similarly, a court probably would imvalidate a governinental contract that contracted away what the court viewed as governmental powers, ${ }^{57}$ or committed the government to enact future legislation, ${ }^{58}$ or simply had too long a duration. ${ }^{59}$

Just as public policy might justify imvalidating contracts, competing values might justify a nonoriginalist interpretation of those documents. In interpretimg a private contract, a court rightly takes account of more than the particular welfare and autonoiny values that underlie contract law. ${ }^{60}$ Such competing values do and should play even a more prominent role in constitutional imterpretation. Any of the severe welfare and justice deficiencies of the original understanding therefore stand as substantial counterweights to any argument based on the real-contract analogy.

An example will clarify this argument. Suppose that the originators of the fourteenth amendment expressly considered and rejected the view that it extended to blacks the right to vote, and that without this understanding, the fourteenth anendment would not have been adopted. ${ }^{61}$ Suppose furtlier that the fifteenth amendment, extending the franchise

56. See, e.g., RESTATEMENT (SECOND) OF CONTRACTS $\$ \S 178-199$ (1979).

57. See, e.g., W. VAlente, Local Government LaW 706-13 (2d ed. 1980).

58. Id.

59. Id.

60. See, e.g., RESTATEMENT (SECOND) OF CONTRACTS $\$ \S 179-199$ (1979).

61. It is clear that the drafters of the fourteenth amendment believed it would be difficult or impossible to secure ratification of that amendment if it included a provision directly enfranchising blacks. See generally J. JAMES, THE Framing OF THE FouRTEENTH AMENDMENT (1956). To this extent, it is in fact true that the fourteenth amendment was not intended to prohibit racial discrimination in the distribution of voting rights; this, of course, accounts for the later adoption of the fifteenth amendment, the drafting and ratification of which involved a substantial political struggle. J. NowaK, R. Rotunda \& J. Young, Constitutional Law 622 (2d ed. 1983). Whether the grant of enforcement power to Congress in section five of the fourteenth amendment would have authorized Congress to enfranchise blacks by legislation has been debated but never decided. Compare Reynolds v. Sims, 377 U.S. 533, 589 (1964) (Harlan J, dissenting) (fourteenth amendment does not allow interference with state power to create inequity in voting rights) with Van Alstyne, The Fourteenth Amendment, the "Right" To Vote, and the Understanding of the ThirtyNinth Congress, 1965 SUP. Cr. REv. 33 (proponents of fourteenth amendment intended its use to enfranchise blacks). 
irrespective of race, had never been adopted. Last, suppose that many people in society acted in reliance on the disenfranchisement of blacks, in deciding where to hive, whether to operate a segregated business, and so on.

Several years later the question of whether the fourteenth amendment prohibits discrimination on the basis of race in voter ehigibility rules arises. On these assumptions, the real-contract analogy seems to provide the basis for a substantial argument for originalism. Does this end the matter, notwithstanding that blacks were unrepresented in the processes that led to the amendinent's adoption, that they might be or might have been a discrete and insular minority unable to secure the franchise by constitutional amendinent, and that disenfranchiseinent on grounds of race is or might be widely regarded as wrong and unjust?

It seems quite impossible to inake a principled defense of the proposition that the welfare and fairness gams supporting originalism deserve recognition but that the welfare, ideal, and justice gains supporting nonoriginalism do not. The justificatory process presupposes that courts should interpret the Constitution in whatever way is best justified, and the good reasons supporting originalist interpretation have no claim in this process to exclusive relevance. Such good reasons, therefore, are always subject to counterarguments based on other social goods or ends of justice clained to be better promoted by nonoriginalist interpretation. Which methodology or interpretation is best justified inust be determined by evaluating these competing justificatory claims on a case-by-case basis. ${ }^{62}$

\section{B. The Constitution as a Deeply Layered Consensus}

Viewing the Constitution as a bargained agreeinent is not the ouly consent-based conceptualization available. The main alternative sees the Constitution as a social contract im the sense that it represents a deeply shared consensus toward certain basic values, like democracy, freedom, equality, and justice. The values represented by these terms have always existed in American culture, and socialization processes probably have the result that most meinbers of American society consider these values as fundainental to our well-being. The values, in other words, form part of the "consciousness" of most individuals in our society. ${ }^{63}$

62. The time at whieh the interpretive question comes up may well be relevant. Exigent welfare considerations, like the relative possibility of one outcome or the other's causing widespread violence, might in fact dictate the outcome, whether or not they ought to. But the main point remains that the real-contract analogy and the values that underlie it do not even in this case necessarily justify originalism.

63. $C f$. T. BenditT, LAW as Rule AND Principle 103-16 (1978) (since function of law is to resolve or regulate conflicts with as little resistance as possible, people must have internal attitudes towards law if the law is to work properly). I ain not persuaded that having internal attitudes 
Justifications based on values like democracy, freedom, equality, and justice might be viewed as irrelevant or as resting on either of two quite different sources of authority, depending on how the process of social value formation is understood. Consider, for example, the claim that equality requires progressive taxes. If we ask whether and why we ought to care what equality requires, three answers seem possible. First, we ought not to care because an appeal to equality carries no more force than an appeal to a ghost. Were this true an appeal to equality would carry no authority, and this simply appears untrue in our culture. Second, we ought to care because equality "really exists" in some sense, so that we ought to do what equality requires in much the same way that we ought not to walk into walls or put our hands in fires. ${ }^{64}$ Third, we ought to care because cultural evolution and our participation in this culture have resulted in us having internal attitudes toward the concepts of "ought" and "equality" such that upon reflection about our "selves," we will discover that we do (or seem) to care. ${ }^{65}$

The third interpretation of the authority of justification employs a "consent" concept that differs from that which underlies the justification of contract. It pictures us as consenting to abstract values, in the sense that, by virtue of our culture and its socialization processes, these values are embedded in our consciousness as constituent parts of our self-identities. Whereas the concept underlying contract views individuals as agencies who choose, the deep-consensus model views the mental state of an individual's "holding values" as a form of consent to those values, and as an event psychologically prior to the individual's particularized choices. To the extent that this interpretation of social-value formation has appeal, the Constitution's authority can be understood as based on a kind of consent theory, as I suggested earher, and therefore on a kind of social contract.

If the Constitution's authority is based on this alternative consensualist conception, however, there is no apparent reason to peg its meaning to the drafters' and adopters' understanding of democracy, freedom, equality, and justice. This remains true even if we make the unlikely assumption that the framers' understanding corresponds to conceptions held by the general population today, mcluding the disenfranchised. If shared stories reflecting norms of political morality are the basis of the Constitution's authority, the document's meaning should change as the

toward or rationally accepting rules is a precondition of "law" or "legal systems." However, the idea that people should value our important political values is an ideological mainstay in our political morality and a presupposition of our governmental system.

64. Moore, Moral Reality, 1982 WIS. L. REv. 1061. I find this claim unpersuasive, if not incoherent. See supra note 20.

65. Professor Rawls, for example, seems to understand the concept of justice in this way. See Rawls, Kantian Construction in Moral Theory, 77 J. PHIL. 515, 517-19 (1980). 
deeply layered consensus embedded in these stories and norms changes. While the document's language as well as the original understanding certainly would be relevant evidence of contemporary norms, they would hardly be conclusive.

On this conception of the Constitution's authority, giving it the meaning intended by the originators would be proper only if today's deep consensus were the same as that during the period of origination. Furthermore, even if this were true, it would not amount to a justification of originalism. The conclusion that the document should be given the meanings intended by the originators would be a consequence not of the status, role, or imstitutions of the origination, but of the happenstance coincidence between originalist interpretations and the interpretations derived from the proper source of meaning, the contemporary deep-consensus social contract. ${ }^{66}$

Originalists might argue that their theory can be justified under this social-contract conception because the deep consensus is stable throughout history. ${ }^{67}$ This argument attempts to transform an empirical proposition about the character and rate of basic ideological change into a normative proposition about constitutional imterpretation. If we make the realistic factual assumption that any deep consensus is less than perfectly stable, the case for an originalist presumption is somewhat undermined. For example, while it seems reasonable to suppose that any deep consensus that generated adoption of some provision of the Bill of Rights (or an amendment) would have some duration through time, it seems entirely unlikely that it would remain fixed forever.

Depending on just how slowly we believed the consensus clianged, thougl, we might favor some sort of rebuttable originalist presunption.

66. Originalism also would need successfully to cope with the claim that the deep consensus is the product of false consciousness. The problem of false consciousness is important but is beyond the scope of this paper. For interesting treatments of this topic, see Balbus, The Concept of Interests in Pluralist and Marxian Analysis, 1 PoL. \& Soc'Y 1 (1971); Benn, "Interests" in Politics, 60 ARISTotelian Soc'Y Proc. 123 (1960); Connolly, On "Interests in Politics," 2 POL. \& Soc'y 151 (1972).

67. There is evidence that, at least on a very general level, attitudes about fundamental values are surprisingly stable over time. For example, a study by Donald J. Devine first identifies, largely on the basis of John Locke's Second Treatise and the Federalist Papers, a set of fundamental political values. Devine then exammes a large body of survey data from the mid-1930's through 1968 for evidence about public support of these values. He finds remarkable consistency over tine in the public support for the general values, both in the population at large and in many subgroups. D. Devine, The Political Culture of the United States 179-230 (1972). Devine and others also found, however, that there is little consensus when it comes to the application of these general values to specific questions. See id. at 332-46 (people favor racial equality as abstract principle but not as applied to specific situations); see also R. Chandler, Public Opinion: Changing AtTitudes on Contemporary Political and Social Issues, a CBS News Reference Book 6-13 (1972) (majority of people do not support application of Bill of Rights guarantees in certain situations); A. MONROE, PUBLIC OpINION IN AMERICA, 168-71 (1975) (same). Other studies are noted in Simon, supra note 14, at 615 n.9. 
The reason for such a presumption would simply be the probable falsity of claims that the deep consensus had changed. Whether we favored this presumption at all, and if so, to what extent, would be a function of our confidence in our beliefs about both the rate of change and the exclusivity of the Court's role. It seems at least highly questionable that we could have sufficient confidence in the underlying social facts to predicate a generally applicable originalist presumption of a consensus that remains coinpletely stable over time, even assuming we were coinmitted to the view that the Court's role is exclusively to interpret our deeply held ideology.

This consensualist defense of originalisin also suffers from a considerably inore important problem. While relatively little is known (and perhaps knowable) about the nature and extent of any deep consensus about norms of political inorahity, it seems quite likely that to the extent people do participate in soine such shared or coinmon consciousness, individuals interpret and apply the paradigmatic stories and general norms quite differently. In other words, the consensus is based on the wrongfulness deinonstrated in particular, concrete stories, as where a black child is prevented from going to a white school, and the propriety of values very abstractly named, like freedom or equahity. ${ }^{68}$

If this is true, then the "deeply layered consensus" foundation for originalisin collapses. The originators, as participants in the assumed shared or common consciousness, could capture the consensus in text or intention only by verbatim repetition of the paradignatic stories or abstract values. To the extent that the text or intention, or both, however, report only the originators' interpretations of the deep consensus and not the consensus itself, the contractarian enterprise fails because the text and intention do not embody the deep consensus; they merely einbody interpretations of it.

The fact that the text and underlying intentions are only interpretations of the deep consensus not only destroys the conceptual foundation of any originalist claim for a presumption that the embodied meanings remain stable, but also provides a very strong reason for the opposite presumption. Since the interpretations of basic values are likely to be biased by the class, sex, race, and perhaps basic lifestyle of the interpreter (whether an origmator or a judge), the proposed originalist interpretation would perpetuate the injustice and disutitity of the exclusionary processes of the origination and the self-interest of the originators. American society would be bound forever to a white, male, propertied interpretation of basic values. ${ }^{69}$

68. Existing social science evidence seems to support the abstract-value view of the deep consensus to a far greater extent than any competing view. See supra note 67.

69. See supra notes $44-48$. 


\section{Contractarianism and the Amendment Process}

Two arguments might rescue the conception of the Constitution as a social contract that still binds us today. The first is that the availability of the amendinent process remedies any justice and welfare deficiencies in the original document, since groups previously disenfranchised are now eligible to participate. The second is that the failure to amend the Constitution implies "popular" consent to the document as written. Both of these arguments are based on the amendment process, but each addresses a different issue. The first argument presents inainly an issue in political morality concerning the extent to which current participation rules "cure" the mjustice and disutility of the original understanding, while the latter presents mainly an issue as to the proper interpretation of pohitical inaction.

The first argument is more theoretical than real, and fails for obvious reasons. The originalist chique was a relatively homogeneous group whose members had overlapping and, to a considerable extent, similar interests and values. The population currently ehgible to participate in the amendment process is extraordinarily heterogeneous, consisting of a bewildering variety of groups with conflicting interests, values, and cultures. Given this heterogeneity, the procedure for constitutional anendment makes the chance for success remote. The legitimacy of the decisions reached by the original chique simply cannot be buttressed by the fact that the legatees of the disenfranchised now have the theoretical possibility of changing those original decisions if they can overcoine virtually impossible pohtical odds.

This problein is even more acute any time society contains groups that are "discrete and insular," in the sense that they are virtually excluded from all attempts at coalition building. ${ }^{70}$ These groups are simply unable to marshal enough votes to protect their interests. They therefore may be subjected to the whims of "the majority." It thus iroincally turns out that the groups most in need of protection will find the amendment process absolutely useless.

The "consent by inaction" argument is also seriously flawed by the difficulty of amending the Constitution, since failure to do an almost impossible act is hardly a rehiable indication of acquiescence. ${ }^{71}$ Suppose, for example, that the supermajoritarian procedures for amendment can only be successfully invoked when seventy-five percent of the voting population favors the amendinent. If so, a failure to amend might mean that

70. For a discussion of "discrete and insular" groups, see Simon, Racially Prejudiced Governmental Actions: A Motivation Theory of the Constitutional Ban Against Racial Discrimination, 15 SAN Diego L. Rev. 1041, 1050 n.23 (1978).

71. Cf. L. TRIBE, ConstrTutional CholCEs 29-44 (1985) (congressional or constitutional silence may have carefully circumscribed significance). 
only twenty-six percent of the population consents to the document as written. Does consent of this sort show popular approval?

Moreover, it seems likely that if any implication about consent from failure to amend can be drawn, it is that inaction implies consent not to the Constitution as written, but to the Supreme Court's contemporary interpretations, for this is the law that governs our lives. ${ }^{72}$ If, for example, the Court has been saying that the Constitution gives women a right to abortion, failure to amend the document to change this status quo must mean consent at most to the Court's imterpretation. While such "consent" does not necessarily imply that the Court's interpretation is the first preference of the populace, it does mean at least that it is preferred to the proposed amendment.

\section{IV \\ The Failure of Abstract InTEntion Theories: \\ THE ORIGINAL Position, CONCEPTS, AND AUTHORITY}

\section{A. Abstract Intention}

Some writers claim that the original understanding should control constitutional interpretation but that the intentions underlying original understanding should not be identified at the level of specific, historically and contextually identifiable goals or exemplary instances. Instead, the intent should be identified more abstractly, in ways that identify the more general purposes of the originators. ${ }^{73}$ This type of theory must first avoid the horns of an almost inescapable dilemma. First, the theory. must define "intention" at a level sufficiently abstract to avoid the perpetration of disutility and mjustice that flows from a concrete-intention theory. However, any theory that rests on a less restrictive interpretive technique is in serious jeopardy of not being based on the "framers" intent." The further the theory strays from the originators' concrete intentions, the less the theory's justification can rely on any notion of "consent" or "agreement."

Recent hterature on constitutional theory supports the idea that abstract-intention theories cannot supply constitutional interpretations rooted in either the original understanding or the framers' intent. For example, Professor Tushnet has argued that no description of framers' intent can capture what the framers meant by the various constitutional provisions. ${ }^{74}$ This knowledge can be gamed only by understanding the

72. Professor Brest has also set forth this idea. See Brest, supra note 1, at 236.

73. See, e.g., Dworkin, supra note 11, at 483-85.

74. Tushnet, Following the Rules Laid Down: A Critique of Interpretivism and Neutral Principles, 96 HaRV. L. REv. 781, 793, 796-997 (1983). Dean Sandalow also has argued for this position to some extent. See Sandalow, Constitutional Interpretation, 79 MICH. L. REV. 1033 (1981). 
historical context in which these particularistic conceptions developed. A historian or court really interested in finding the framers' meaning therefore must use what some people have called a "hermeneutic" approach, which calls for the imterpreter to enter the minds of his or her subjects, see the world as they saw it, and understand it in their own terms. ${ }^{75}$ It seems quite likely that when one person "enters another's mind" to report to us what that person really beheves, the report will be more than a bit affected by the enterer's own predispositions.

Professor Bennett argues more directly that no matter how specific and historically contextual the framers' intent, there is considerable room for the future interpretation of constitutional provisions. ${ }^{76}$ These subsequent interpretations must depend on the value judgments of interpreters and cannot in any realistic sense be bound to or guided by the framers' state of mind.

This proposition is true on either of two accounts of what the object of the framers' intentions was. First, the object of their intentions may have been to reach certain goals. Perhaps, for example, the correct description of the intention behind the fourteenth amendment is that the framers wanted the former slaves not to be demied equal treatment in matters that concerned fundamental rights. But the decision regarding which forms of dissimilar treatment should be outlawed im order to further this goal will change through history, depending largely on the judgment of interpreters. Second, the object of their intentions may have been exemplary instances. Perhaps, for example, the framers of the fourteenth amendment wanted to prohibit the imposition of disabilities agamst the former slaves like that accomplished by the infamous Black Codes. In that event, the shape and direction of any analogical extension will depend largely on the judgment of interpreters, and must change through history as new analogues or cases arise.

Uuless these criticisms are satisfactorily answered, the conclusion seems warranted that abstract-intention theories are not origimahist. If the apphication of the originators' general goals or exemplary instances to cases and controversies depends on judges' changing behiefs as to which means further the goals or which other instances are "like" the exemplars, the resultimg method of interpretation imposes too httle constraint on judicial choice to be called origmalist in any meaningful sense. This criticism might be answered by the argument that it is the origmators' means-goals judgments or analogical beliefs that should control interpretation. But, aside from the practical problem it poses, how could such a claim be justified? Abstract origmatism, conceived in this way, could not

75. See Tushnet, supra note 74 , at 799.

76. Bennett, supra note 14, at 460-74. Professor Moore has also at least implicitly argued this position. See Moore, The Semantics of Judging, 54 S. CAL. L. REv. 151, 246-70 (1981). 
be justified on contractarian grounds for the same reasons, as we have seen, that concrete originalism cannot be so justified.

Even if an abstract-imtention version of originalism could be developed, originahists would need to respond to the commonsense criticism that such a technique might fail to capture the meaning that the concepts embodied in the Constitution had for the framers. Suppose, for example, that the creators of the fourteenth ainendment wanted to achieve the goal of "equal treatment" for blacks and whites, but believed that segregation of facilities was not unequal. If a later generation beheved that segregation as it had developed did not provide equal treatment, is it more faithful to the framers' intended ineaning to permit or prohibit the disagreeable practices? Should the interpreter rely on current or past interpretations of the "equal treatment" concept?

Finally, any version of originalism must be justified. Can any abstract version of "the original intention" be defended on social-contract grounds? To what extent can the interpreter's application of the originators' view of the world to the current situation really be considered an interpretation of any original understanding, and consequently be justified on the basis of the originators' contract? These questions can best be approached by first considering what is probably the best known version of social-contract theory to have been developed in recent years, that set forth by Professor Rawls in A Theory of Justice. ${ }^{77}$ Rawls's attempt to base his principles of justice on a contract that would be negotiated by hypothetical parties in an original position is directly relevant to abstract-intention theories in constitutional law. The following sections demonstrate why Rawls's theory really is not a contract theory and why Rawls camıt justify his principles of justice, and abstract originalists camıt justify their constitutional values, on the basis of consent in the original position or to the original understanding.

\section{B. Rawls and Social Contract}

To develop his theory of justice, Professor Rawls deploys an originalist-like concept called the "original position."78 The original position is conceived of as a bargain-like situation, where the parties know nothing about themselves except that they are human beings. ${ }^{79}$ For example, they have no knowledge of their values, interests, wealth, or skills. According to Rawls, the social norms and arrangements

77. J. RAWLS, supra note 30.

78. Professor Rawls's theory is set out in full in his book, $A$ Theory of Justice. However, his subsequent writings shed nore hight on the book's conceptual foundation. See, e.g., Rawls, supra note 65; Rawls, A Well-Ordered Society, in PhiLosophy, Politics \& Society 6 (P. Laslett \& J. Fishkin eds. 1979).

79. J. RAwLS, supra note 30 , at 11-22. 
required by justice are the ones to which the negotiating parties would agree. ${ }^{80}$

Two characteristics of the original position inake it a powerful heuristic. The first is the dramatic device of getting us to think about people who inust bargain and reach an agreeinent before any distribution of resources and (perhaps) values is made. This is a powerful way of making vivid the sort of "neutral" perspective that some beheve is required for addressing questions of justice. The second characteristic is the framing of the question as if its answer depends on contractual conceptions. This characteristic appears to solve the problem of the authority for the resulting principles of justice on the basis of consent.

This second characteristic is in fact misleading. Conceptualizing the derivation of the principles of justice on the basis of contract creates the illusion that the same autonomy and pareto norms that justify contract also justify the principles of justice. The fact that no one alive today was party to Rawls's hypothetical contract any more than anyone now hiving acquiesced to the original understanding of the Constitution suggests this is an illusion. The authority for imposing Rawls's principles of justice obviously cannot depend on the fact that we or our representatives consented to them, because neither we nor our representatives did.

More specifically, the authority of these principles cannot be based on respecting any particular individual's autonoiny or moving any specific person to a pareto superior position. The autonony and pareto norins that justify the authority of normal contracts presuppose that the contracting parties have identities and interests, for it is only in such cases that the concepts of "choice" and "welfare" have operational meaning. To the extent that the norms and arrangements in our real society fall short of the Rawlsian vision, Rawls's principles cannot be authoritative because people presumably take the requisite attitude not towards Rawls's vision but towards existing norns and arrangements.

In one sense, of course, this is an unfair criticism. Rawls's purpose is not to estabhish that people have in fact consented to or taken an attitude towards his vision, but rather that they "ought" to. He is trying to determine which principles of justice are best justified, not which would be agreed to if a poll or election were conducted. For purposes of justifying an originahist approach to constitutional interpretation, however, the criticism is quite important since Rawls's enterprise appears to depend both for its conceptual foundation and its persuasive appeal upon a rather odd concept of consent.

If Rawls's theory attempts to justify certain normative principles of justice, the important question is what characteristics of his consent the-

80. Id. at 12 . 
ory actually support the principles of justice that allegedly follow. The answer depends more on justice than consent. To the extent it does depend on consent, the answer has much more to do with deep consensus than contract theory.

People ought to be persuaded by Rawls's argument for two reasons. First, it is imtrinsic to the very idea of appraising the justice or fairness of basic social norms and arrangements that the appraisal be conducted from a perspective that is im some sense neutral, ${ }^{81}$ since otherwise the appraisal will be biased by the appraiser's values, interests, and expectations. ${ }^{82}$ Second, if people stripped themselves of their identities, they would all arrive at the conclusions Rawls draws about the principles of justice, for precisely the reasons hc provides. ${ }^{83}$

If this imphicit line of argument is successful, we can characterize a unanimous agreement over the primciples of justice as a "contract," since everyone would have come to agree both with Rawls's concept of justice as requiring neutral perspectives and with the allegedly mevitable conclusions that follow. But when the concept of "contract" is used in this fashion, it is perfectly clear that we are using it not to justify the agreement about the principles of justice, but to sunimarize the fact that his concept and arguments are so persuasive that everyone agrees with them. The "contract" is but the wagging tail on the dog of "justice."

Although Rawls describes his theory as one based on "contract,"84 it is quite difficult to see what is gained by this conception, beyond its dramatic impact. Umiversalization, not actual agreement, is the driving idea behind the original position, an idea equally captured by older concepts like "the public interest," or Rousseau's "general will."85 Put differently, Rawls appareutly could have derived his principles of justice equally as well by asking what basic arrangements for society one person would develop if he or she were constrained to choose arrangements that were "in the interests" of all persons.

The basic problem is that even if all people viewed themselves as the originators of the Rawlsian contract, it is not the fact of agreement that justifies the principles of justice reached but the "good reasons" underly. ing that agreement. Correspondingly, if a question came up later about the proper "interpretation" of the contract, the intentions underlying it (the original understandmg im the original position) would be norma-

81. Id. at 260-63 (justice not dependent on individual wants and interests).

82. Id. at $12-13$ (idea is fair because no one able to create conditions favorable to his or her situation).

83. These reasous include, for example, claims about how people would balance their desires for maximum individual liberty agaiust inaximum social welfare. See generally id. at 118-92.

84. Id. at 16-17.

85. This poimt also is made, if somewliat obliquely, in both W. NELSON, supra note 29, at 104, and Ryan, supra note 37 , at 39,55 . 
tively relevant not because they reflect the content of the agreement, but because they may provide some evidence of what justice requires. The requirements of justice that "caused" the hypothetical agreement, in other words, ought to determine the "interpretation" of any ambiguities in it. ${ }^{86}$

This poses for Rawls the following problem: since the justification of the agreement is based not on consent but on the "good reasons" underlying the agreement, on what authority can Rawls claim that these reasons are in fact "good"? In fact, why should Rawls's "question of justice" 1natter at all, why does it require a neutral perspective of the sort he invokes, and why does it lead to his conclusions?

Rawls probably derives the principles of justice from what he views as a deep consensus in our society over basic norms of political morahty. In other words, perhaps justice exists and demands some sort of neutrality because everyone beheves that it does. Furthermore, we find corroboration for our intuitions when we critically reflect on the kinds of questions we think relevant to the evaluation of political actions. To the extent this is so, we ourselves are the source of authority for the principles of justice, for we agree at least that the concept exists, has soinething to do with neutral perspectives, and is relevant to evaluating pohtical action. $^{87}$

The view that a deep consensus is the source of norns of political morahity, as noted earher, ${ }^{88}$ can be interpreted as a social-contract theory. It also appears to be consistent witli basic tenets of deinocratic theory that see "the people" as the source of all autliority. Indeed, the very structure of Rawls's heuristic suggests that lie sees soine sort of deep consensus as the source of authority for his claims. ${ }^{89}$ His central con-

86. Bernard Williams makes a similar point in arguing that Rawls's assumption that the original choice be a final choice "comes perilously close to a requirement on the original choice, that it be of a system which will be just-which of course would be to moralise the original choice itself, and to put in at the beginning what we are supposed to get out at the end." B. Williams, Moral LuCK 95 (1981). See also R. WolfF, UNDERSTANDING Rawls 180-83 (1977); Nagel, Rawls on Justice, in READING RAwIS 5 (N. Daniels ed. 1976). Many critics, of course, have disputed Rawls's claims about that to which those in the original position would agree. See, e.g., Buchanan, $A$ Critical Introduction to Rawls' Theory, in JOHN RAWLS' THEORY OF SOCIAL JUSTICE 5 (H. Blocker \& E. Smith eds. 1980).

87. None of this, of course, commits us to Rawls's interpretation of justice, nor does it bind us to any claim that justice is prior to or more miportant than other values. It does, however, commit us to taking the question seriously.

88. See supra text accompanying notes 63-69.

89. Rawls's subsequent writings also make this point. For example, Rawls later said:

[C]onditions for justifying a conception of justice hold only when a basis is established for political reasoning and understanding within a public culture. The social role of a conception of justice is to enable all members of society to. 1nake mutually acceptable to one another their shared institutions and basic arrangements, by citing what are publicly recognized as sufficient reasons, as identified by that conception. . . . Thus, whenever a sufficient basis for agreement among citizens is not presently known, or recognized, the 
cepts certainly are Kantian more than Marxist, ${ }^{90}$ and correspond more highly to post-Enlightenment Western political thought than to that of earlier eras or different societies. This is true both for his assumptions about the kinds of things that parties in the original position would value (e.g., material well-being and liberty rather than God, family stability, or love) and for his more basic assumptions, like the justice-as-neutrality view (and the Kantian nonembodied "free will" concept on which it is at least partly based) that underlie his use of the original position. ${ }^{91}$

Whatever the answer to this question of authority, Rawls's theory of justice no more rests on the hypothetical original understanding than the authority of the Constitution rests on a real one. This authority must be sought elsewhere, and I have suggested that a theory about deep consensus seems the most promising source.

\section{Dworkinian Concepts and Conceptions}

Any abstract-intention theory of constitutional interpretation that employs an imterpretive technique sufficiently liberated from concrete intention faces the same difficulty as Rawls's theory of justice. This is certainly true of perhaps the best known abstract-intention theory, that of Professor Dworkin.

task of justifying a conception of justice becomes: how can people settle on a conception of justice, to serve this social role, that is (most) reasonable for them in virtue of how they conceive of their persons and construe the general features of social cooperation among persons so regarded?

...

. . The aim of political philosophy, when it presents itself in the public culture of a democratic society, is to articulate and to make explicit those shared notions and prineiples thought to be already latent in common sense; or, as is often the case, if common sense is hesitant and uncertain, and doesn't know what to think, to propose to it certain conceptions and principles congenial for its inost essential convictions and historical traditions.

...

... What justifies a conception of justice is ... its congruence with our deeper understanding of ourselves and our aspirations. . . .

Rawls, supra note 65, at 517-19.

Wolff describes Rawls's theory as based on "the 'rational reconstruction' of ordinary inoral consciousness." R. WoLfF, supra note 86, at 181.

90. Compare Darwall, Is There a Kantian Foundation for Rawlsian Justice?, in JoHN Rawls' THEORY OF Social Justice 311 (H. Blocker \& E. Smith eds. 1980) (Rawls consistent with and extends Kant's insights into autonomy, respect for reason, and interplay between reason and morality), with DeMarco, Rawls and Marx, in JohN Rawls' Theory of Social Justice 395 (H. Blocker \& E. Smith eds. 1980) (Marxist thought challenges Rawl's notions of original position, difference principle, and priority of equal liberty and equal opportunity). See also R. WolfF, supranote 86 , at $101-16$.

91. Bernard Williams puts the point succinctly. "Rawls' theory tries, in effect, to link politics with morality, and morality . . . to a self-imterested choice under uncertainty. He indeed links politics with a Kantian conception of morality, but the supposed choice under uncertainty seeins in fact to have the morality already packed into it. . . " B. WILLIAMS, supra note 86, at 100 . For an interesting discussion of soine of these issues, see M. SANDEL, LIBERALISM AND THE LIMITS OF JUSTICE 168-83 (1982). 
Dworkin draws a distinction between concepts and conceptions that is similar, if not identical, to the one I have drawn between the deep consensus and particular interpretations of it. ${ }^{92}$ Dworkin then argues that the originators' intent is the authoritative source of constitutional norms, but that courts should identify this intent at the abstract level of concepts (or what I would call the deep consensus). ${ }^{93}$

Dworkin's theory fails for two reasons. First, the theory never justifies Dworkin's choice of abstract over concrete intention, and it seems unjustifiable on "consent" grounds. Second, Dworkin has not supphied any other justification besides consent. Even if he could establish that the originiators really intended their abstract intention to control or intended to delegate broad interpretive discretion to courts, given the failure of a consent-based justification, Dworkin's theory provides no rationale for following either of these intentions.

An interpretation of constitutional language that differs from the understanding that the originators would have had of that language plainly cannnot be said to capture the originators' concrete imtention. Yet in Dworkin's view, it would have been perfectly proper for the Court to give a constitutional provision an alternative interpretation which was considered and rejected by the framers. I do not necessarily object to this outcome, but absent some unspecified additional theory, ${ }^{94}$ this approach cannot be based on any theory of original intention.

Furthermore, even if an additional theory were developed and deployed, it does not follow that the courts should take on the task of interpreting their concepts on abstract intention (or deep consensus) simply because the originators wanted them to do so. This role would follow only if the original understanding is, or ought to be, authoritative. To this point at least, no one has developed sound reasons for believing this to be true.

Consider the case where two people hold very different interpretations (or conceptions) of the deep consensus (or concepts). A third person miglit believe tliat one or the other is a "better" interpretation or conception, or even that his own very different interpretation is the "best." It seeins nonsensical to believe, lowever, tliat all three people hold the same interpretation or conception by virtue of the claim that either in motivation or justification, or both, all interpretations depend upon the same deep consensus or concept.

92. See R. Dworkin, TAKING Rights SeriousLy, 132-37 (1977); Dworkin, supra note 11, at 488-97.

93. R. Dworkin, supra note 92, at 147; Dworkin, supra note 11, at 496, 497.

94. One such theory might be that the originators also intended to delegate to courts the power to reach different interpretations of the deep concensus. See, e.g., Bickel, supra note 2, at 4-6 \& n.14. 
Now suppose that one of the three is authorized to write his conception into a law that will bind everyone. To say that this act of lawmaking is "authorized" presupposes either that everyone takes an appropriate attitude toward the author or writing that lends the act authority, or that everyone beheves the act is justified, or both. What follows is that the author's conception is authorized and the other two very different ones are not. If it is later suggested that the law should be interpreted in accordance with one of these different conceptions, questions concerning the authority for such a reinterpretation would arise. It might be argued that the interpretive imstitution has such authority because ideas about authority have changed. It would, however, be very odd to call this modification either an imterpretation of the original understanding or an interpretation based upon the authority of the original understanding.

Professors Dworkin and Rawls thus face the same problem. The original understanding must be conceptualized either as a real agreement among real people with real interests and values or as a hypothetical agreement annong disembodied ideological spirits. Only under the first conceptualization, however, can the authority of the agreement be based on the autonomy or pareto norms underlying consent theory. But this theory of authority inevitably points towards a concrete intention theory of interpretation that, as we have seen, cannot itself be justifed by reference to either the autonomy or pareto norm.

Under the second, "disembodied," conceptualization, the Constitution's authority cannot be based on these autonoiny or pareto norms at all, since they presuppose contracting parties with identities and interests. Consequently, absent elaboration not provided by Professor Dworkin, there is no justification for interpreting the Constitution in accord with "disembodied" framers' intentions. Moreover, use of the term "framers' intentions" would seem to be nothing but a misleading reference to whatever ideological implications the imterpreter has built into his or her disembodied ideological spirits.

Abstract-imtention theories like Dworkin's can avoid this difficulty only by arguing that I have somehow misdescribed the facts concerning our Constitution's origin. One route for such an argument would claim that the originators had concepts but no conceptions. This seems a very unlikely story to tell about real people. The theory that the framers had conceptions but didn't care if different ones were immediately substituted for them seems equally unlikely.

Only two other kinds of arguments are available. The first would invoke concepts of delegation and would argue that the originators intended their own conceptions to control interpretation for their contemporaries, but intended to permit different conceptions of the underlying concepts at later points in history. Professor Bickel, for example, 
argued that the existence of such an intention explained why Brown $v$. Board of Education ${ }^{95}$ was not inconsistent with the original understanding of the fourteenth amendinent, notwithstanding that the originators did not intend to outlaw racial segregation..$^{96}$

A second and related argunent would claim that the originators had no intentions relating to constitutional interpretation in the distant future. Insofar as the framers understood theinselves as producing a bargained contract, their intentions are inost realistically understood to be limited to the period when their interests were implicated. Insofar as the framers understood themselves as correctly interpreting the deep consensus, they were wise enough to know that interpretations that seen "correct" to one generation 1might quite reasonably see1n "1mistaken" to later ones.

While either the delegation or no-intention view would free interpretive institutions froin the originators' interpretations or conceptions, neither theory authorizes taking advantage of that freedoin. In the absence of the authority that coines froin popular attitudes or provision of good reasons, there is no more reason for the Court today to follow these theories of original intent than there is for it to follow any others of the original intentions.

Without appeal to originalisin, the justification for the Court's behavior inust coine from soine other direction-for example, froin the development of a political theory that directly justifies the Court's interpreting the deep consensus. Under such a theory, the language of the Constitution and the original intention might be important evidence for an originalist interpretation. Its authoritativeness would derive not from originalism, however, but froin the persuasiveness of the deep-consensus political theory. The nature of the basic problein here should be clear from our examination of Professor Rawls's theory of justice.

\section{$\mathrm{V}$}

\section{ORIGINALISM's GoOdNESS AND JUSTICE: THE "Rule OF LAW" ViRTUES AND THEIR COUNTERWEIGHTS}

The final and inost promising argument in support of originalist interpretation would confront the matter of justification directly. It would claim that the Court should follow the plain meaning of the Constitution or the intentions underlying unclear and open-textured constitutional provisions because goodness and justice are best promoted by this course of action. At least some passages in writings that support

95. 347 U.S. 483 (1954).

96. Id. The historical basis for this particular claim, as well as that of delegation claims in general, has been hotly contested, see $\mathrm{R}$. BERGER, supra note 2 , at $117-28$, and is a subject on which I have no view. 
originalism ${ }^{97}$ suggest that their authors beheve this is a viable possibility, although I am not aware of anyone who makes a serious attempt at such a justification.

The best attempt to justify originahsm in this way would probably rest on what I shall call "rule of law" virtues. The principle virtues of the rule of law are that like cases are treated alike, that behavior can be chosen on the basis of predictable legal consequences, that the law is relatively stable and changes are reasonably predictable, and that its stability and predictability reduce the costs of enactment, enforcement, and dispute resolution. ${ }^{98}$

This Part will show that while these virtues do provide some support for originahst interpretation of some constitutional provisions, they do not justify originalism as either a general or exclusive method of interpretation. Furthermore, I will demonstrate that they do not justify an originahst approach to imterpreting the open-textured provisions of the Constitution that are the source of most extant rights.

In this Part, I suggest that several theories of constitutional interpretation might be impled by the rule-of-law virtues and by competing visions and values. Simce im this paper I generally do not consider either the relationship between democratic theory and judicial review or the extent to which various theories mesh with transient public preferences, I do not wish to be taken as proposing any or all of these theories as either completely justified or workable. I raise them merely to highlight the deficiencies of originalism, and to help explain how and why constitutional development may have taken the shape it has over the past two centuries.

As this concession miphes, proving that originahism is to a considerable extent unjustifiable does not settle the question how the Court should interpret the Constitution. It is worth emphasizing at the outset what can and cannot be established by showing that this justification of originalism fails. Most importantly, nothing about the failure of originalism necessarily demonstrates the proper allocation of authority between the judiciary and the elected branches of government. To the extent that originahsm is unjustified, legislative bodies and courts are in principle equally free of originahist constraints. The intial question regarding the proper allocation of authority among contemporary institutions will depend on what allocation of authority can be most persuasively justified on the basis of democratic theory or, what amounts to the same thing,

97. For example, while Professor Berger's discussion of "Why the 'Original Intention'?" is none too clear, one might read his defense of originalism as based in part on the need for certainty. R. BERGER, supra note 2, at 364 .

98. L. Fuller, The Morality of Law, 33-94 (1964); R. Sartorius, Individual CONDUCT AND SOCIAL NORMS, 163-79 (1975). 
the promotion of a good and just society. ${ }^{99}$

Moreover, the allocation of authority that can be best justified as a matter of pohtical theory may or may not be feasible as a matter of pohtical and social reality. While there may well exist a deep consensus on abstract values relevant to political morality, both common sense and social-science research indicate that individuals' attitudes toward the Constitution and their imterpretations of the deep consensus vary widely. ${ }^{100}$ The best justified allocation of authority and, more importantly, the outcomes such allocation would permit might be too unpopular to implement, even if a failure of implementation would be unjust. ${ }^{101}$

\section{A. Authority, Democracy, and the Rule-of-Law Virtues}

Professor Moore describes the rule-of-law virtues as "those values that mandate that judges should not just dispense justice in some ad hoc, case by case basis. Such values are often called the 'rule of law vitues,' and a system for resolving disputes that possesses sucli virtures we honor with the phrase, "legal system." "102 Above all else, the concepts of "law" and "legal system" imply that interferences by individuals or groups in the lives of others should not be "arbitrary"-a requirement whose importance is exceeded only by its lack of clarity. ${ }^{103}$ The concept is unclear both because it is comprised of at least two different historical strands, and because the criteria of arbitrariness are not supphed by nature and are to soine extent controversial.

The classical articulation is that government must be of law and not of rulers. This articulation embodies an ideal that is far from attainable, however, for its full implementation presupposes that all positive law is logically deduced from the nature or edicts of an authoritative outside source. These edicts, however, will lose their objectivity when they suffer the inevitable manipnlations by huinans. Even in societies in which law is fervently beheved to be wholly deducible from rehigious or supernatural concepts, it is clear at least from an external perspective that the process of deduction requires human interpretation of the resulting concepts

99. To repeat, the question is simply and only one of justification. No "objective truth" stands waiting in the wings. See supra note 20.

100. See Simon, supra note 14 , at 615 n.9.

101. Of course, what is unpopnlar in one year imight be popular in the next. But it has been clear at least since the New Deal and probably since Alexander Hamilton coined the phrase "the least dangerous" branch, THE FederAlisT No. 78, at 143 (A. Hamilton) (C. Rossiter ed. 1964), that the Supreme Court lacks the power to ram its program down the nation's throat, even assuming it should.

102. Moore, A Natural Law Theory of Interpretation, 58 S. CAL. L. REv. 279, 313 (1985) (emphasis added).

103. L. FULLER, supra note 98 , at 33-94. 
and human administration of the resulting positive laws. ${ }^{104}$

The growth of modern pohitical theory became both possible and necessary because of the demise of the supernatural view of law. ${ }^{105}$ When positive law was beheved to have its source in a divine or infallible agent or a natural order, or rulers were beheved to rule by divine or natural right, the authority of government was based on attitudes of individuals toward those wider behief systens. From its inception, modern political theory has atteinpted to discover and articulate a theory about authority that can serve as an acceptable substitute for the behef in the authority of an outside entity or order, religious or otherwise.

Our own political theory, "democracy," locates this source of authority in tlie members of society. The most miportant consequence of this theory of autliority has been that the people should have supervisory riglits over governing bodies, exercised primarily through an election process.

Political belief systems, lowever, normally cliange incrementally. New beliefs often emerge as interpretations of older ones or become interwoven with them. Over time, therefore, it was perhaps inevitable that the democratic conception of the people as the source of authority came to be interwoven witl the older idea of the rule of law.

While the two ideas are highly interrelated and to some extent mutually reinforcing, it is important to distimguish between them for at least two reasons. First, the idea that arbitrary interferences with people's hives should not be tolerated does not necessarily preclude nondemocratic political theories or systems. It is possible to distinguish between the morality of a political system's source of authority and the extent to whicl it complies with the nonarbitrariness principle. We might, for example, beheve completely unjustifiable the clami that a king rules by divine right or that a commumst party rules by virtue of Marxist doctrine concerning the class struggle. But a particular king or comınumist party miglit govern througli positive laws that to a greater or lesser extent carry the virtues thouglit to be characterized by the rule of law. ${ }^{106}$

The second reason for distinguishing between the principle of nonarbitrary governance and virtues of democracy is that it is not clear to what extent any of the political systems commonly called democracies satisfy

104. The most perceptive discussion of the richness and complexity of this process can be found in 2 Q. Sxinner, The Foundations of Modern Political Thought (1978).

105. See id. at 349-58.

106. This might be true, for example, if the non-arbitrariness principle is given a minimalist mterpretation requiring only that executive action harming individuals be taken in compliance with positive law, and if the regime in fact observes this requirement.

Although not directly on point, it is useful to recall that nondemocratic laws and legal systems can qualify as "laws" or "legal systems" under H.L.A. Hart's concept of law. H.L.A. HART, THE CONCEPT OF LAW, 114 (1961). 
the requirement of nonarbitrariness. The answer to this question depends partly on the definition of "nonarbitrariness." Under some interpretations of the nonarbitrariness principle, for example, the possibility that many laws are enacted for the purpose and with the effect of benefiting some people at the expense of others would subject our system to a substantial arbitrariness criticism. ${ }^{107}$

The rule-of-law virtues most relevant to originalism as a method of constitutional interpretation are derived from the older nonarbitrariness requirements, that is, fornal equahty, predictability of legal consequences, stability of law, and efficiency in lawmaking and enforcement. Claims for originalism based on the deference courts ought to pay contemporary, electorally responsible imstitutions are based not on these virtues but on the claimed virtues of democracy, which may mclude some particular doginas about arbitrariness as well. ${ }^{108}$ While there is a connection between the older nonarbitrariness principle and democratic theory, it is not an important one for present purposes, ${ }^{109}$ and therefore the nonarbitrariness principle can be considered separately froin the question of the proper sources of authority im a democracy and the imphications of democratic theory for judicial review.

\section{B. The "Equality" Rule-of-Law Virtue and Originalism}

The rule of law is thought to have the virtues of fornal equality because instances that are alike in relation to the purpose of the law must

107. This might be true if the nonarbitrariness principle is interpreted to require governmental comphance with a substantive moral theory that excluded governmental action like that posited in the text. Insofar as utilitarian-based theories of democracy are concerned, the principal debate has been over the extent to which isolated governmental actions which in purpose and effect benefit some at the expense of others are best understood as part of a larger process of logrolling or vote-trading which is itself (nore or less) consistent with utilitarianism. See, e.g., Bennett, "Mere" Rationality in Constitutional Law: Judicial Review and Democratic Theory, 67 CALIF. L. REv. 1049, 1067-69 (1979); Wilson, supra note 45, at 332-33.

108. To the extent that these claims are particular to democracy, they are rooted in assumptions or assertions about the source of authority in a deinocracy. Typically, they depend on both the correctness and the exclusivity of the "supervision through elections" interpretation of the authoritativeness of the people. While I think it clear that this is a correct imterpretation, it is not necessarily the exclusively correct one. The deep-consensus theory which $I$ have alluded to throughout this paper and hope to explore more fully in the future is at least another candidate. But see J. ELY, supra note 26, at 63-69 (partially effective criticism of "consensus" theories).

109. In order to promote the older rule-of-law virtue of fornal equality, one must interpret its requirement that like eases be treated alike. Given its nornal minimalist imterpretation, namely, that cases alike in relation to the purpose of the law should be treated alike, the requirement is meaningless without constraints on the legitimacy of purposes. Any such systein of constraintsoptimally, a theory and catalogue of illegitimate purposes-will be completely dependent on moral and political theories, and for this reason the meaning given the older arbitrariness principle cannot be completely separated from democratic theory issues. For probably the best discussions of many of these issues, see Bice, Rationality Analysis in Constitutional Law, 65 MINN. L. REV. 1 (1980); Sunstein, Public Values, Private Interests, and the Equal Protection Clause, 1982 SUP. CT. REv. 127. 
be treated alike. ${ }^{110}$ For our purposes it is sufficient to say that this virtue has both a spatial and a temporal dimension. Spatially, formal equality requires that when two persons' rights or obligations are adjudicated at the same time, those people should be treated the same if the persons are in all respects similarly situated. The temporal dimension requires the same declaration of rights or obligations for similarly situated litigants even at different times. The latter, however, is more elusive because the very difference $m$ time will often, if not always, suggest that the litigants are not similarly situated.

An attempted justification of originalism on the basis of formal equality values, while neither inconceivable nor entirely without force, would on balance be quite weak. Since originalism would result in unclianging rules of constitutional law, it arguably would proinote the temporal aspect of formal equahity better tlian alternative interpretive methods that can result in clianges in the rules over time. This arguinent, however, fails under closer scrutimy, for any systein of interpretive methodology satisfies tlie temporal equality requirement. Assuming that there are good reasons for adopting an interpretive inethod tliat allows the rules to cliange over time, the liypotlietical litigants at different times will virtually always be differently situated. By definition, then, the requirement is always satisfied. The real issue here is not formal equality but the relative justifications of the two positions on whether the rules should be unclianging.

With respect to the spatial dimension, originalism will not necessarily promote formal justice better than alternative interpretive methods. On this issue, originalism would be superior to otlier metliods to the extent it produces clearer constitutional rules or standards, since lower court judges are likely to apply ambiguous and unclear standards differently to tlie same facts, and appellate supervision may be less than perfect. On the other hand, originalisin would greatly reduce the number of federal constitutional rights, with the likely effect of greatly increasing the disparity in rights held by citizens who are similarly situated except

110. See supra text accompanying note 98. This prerequisite to calling something "law" is applicable to law in its creation as well as in its application, and on this basis it might be conceptually possible to argue that some provisions of the Constitution are not law (properly so called) at all. Such an argument could be successfully inaintained, however, only by somehow ruliug out very particularistic (and probably often aceurate) characterizations of the originators' purposes. If the purposes are sufficiently narrow and specific, even rules applicable only to named persons count as law. This argument, in turn, would depend on ruling out some purposes as impermissible on moral grounds. Because this chain of reasoning seems to be a Rube Goldberg way of addressing moral issues that can be addressed directly, I will not pursue it. The resolution of other formalequality issues in the debate over originalism is similarly dependent on the answers to prior questions, so that formal equality is rcally ouly "formally" implicated in this debate. This is but another example of the equality norm in moral discourse. See Westen, The Empty Idea of Equality, 95 HARV. L. REV. 537 (1982); see also supra note 109. 
for their state of residence. Whether this effect is to be counted as a decrease in formal equality depends on whether the difference in state residence is a relevant distinction. If state residence should not be a relevant basis for the distribution of basic rights, it would be difficult to know whether originahsm better proinotes spatial equality than do competing methods of interpretation. ${ }^{11}$

\section{Other Rule-of-Law Virtues and Originalism}

The other rule-of-law virtues are significantly interrelated and are important for several reasons. First, to the extent the rules of constitutional law are certain and stable, administrative costs are reduced, legislative and administrative bodies can take action with relatively clear expectations about the Court's likely response, and lower courts can be relatively confident of appellate court responses. Second, constant change in basic rules or institutions probably imposes psychic and other costs on the individuals affected, both because people may have acted in rehance on the old rules or imstitutions, and because most people probably find constant change distressing and disorienting. Third, rule and institutional change probably produce significant startup costs, as society attempts to adapt to changes. Fourth, the existence of a clear rule or an unambiguously functioning institution may in some areas be more important than the content of the rule or design of the institution. ${ }^{112}$ Fifth, the state of the world under rules and institutions that have been in place for some time is known, whereas the effects of change can never be known in advance.

Three kinds of arguments undermine this case for originahsm. First, stability of expectations may sometimes be better or at least as well produced by nonoriginalist interpretation. Second, change and unpredictabihty inay be virtues as well as vices. Third, since these arguments for originahisin presuppose that the Court should interpret the Constitution to promote social good, they are subject to counterarguinents based on other social goods that may be better promoted by nonoriginalist interpretation.

111. The decision as to whether state residency is a proper distinction for allocating rights raises questions of political theory dealing with the proper allocation of jurisdiction over civil rights and liberties in federated governmental systems. The answer depends on such considerations as the relationship between government structure and the protection of minority groups; the possibility and desirability of allowing people to choose by residence the laws to which they will be subject, including not only the freedom-of-choice consequences but also the consequences for residential segregation by class, race, or ideology; and the extent to which at deep layers of consciousness we are as a nation committed to all of our citizens having certain basic rights.

112. Cf. Rawls, Two Concepts of Rules, 64 PH1L. REv. 3 (1955). 


\section{Stability of Expectations and Constitutional Interpretation}

Even if stability and predictability are vital, society often might opt for a nonoriginahist interpretation of key constitutional provisions. Stability and predictability values are not equally imphicated by all constitutional provisions, or equally threatened by all possible nonoriginalist interpretations. Constitutional provisions that invoke the real-contract analogy strongly implicate such values because they create relatively concrete expectations and are relatively likely to induce detrimental reliance. Clauses banning states from impairing the obligations of contract ${ }^{113}$ or prohibiting the federal government from taking private property for a public use witlout just compensation ${ }^{114}$ are obvious examples. Stability and predictability provide strong arguments against interpreting these provisions im ways that defeat expectations, and therefore against some nonoriginalist imterpretations. ${ }^{15}$

The constitutional provisions creating the three branches of the federal government and specifymg the procedures for amendment also strongly implicate stability and predictability values. Constant and unpredictable cliange in rules that are constitutive of imstitutions would create confusion and uncertainty over these basic institutions. ${ }^{116}$

Finally, stability and predictability values are implicated, though not so strongly, by any constitutional provision whose textual meaning is quite specific and whose application is quite clear. Provisions in Article I, for example, prohibit both the Umited States and all states from granting any "title of nobility," 117 and the third amendment prohibits the quartering of soldiers im private liomes " $m$ time of peace . . . witliout the consent of the owner." 118 The very specificity and relative clarity of these rules at least weakly implicates stability and predictability values, not because of rehance or imstitutional integrity values but for the simple reason that "rules are rules."119 The widespread failure of courts to follow such rules imight undermine stability and predictability values because such behavior is mconsistent with the concept of a rule. In the long run, it might even undermine the idea that rules exist. Stability and predictability values at least presumptively justify giving such rules their plain, "originalist" meaning.

Even with regard to constitutional provisions that clearly implicate stability and predictability values, the case for originalist interpretation is

113. U.S. CoNST. art. I, § 10, cl. 1 .

114. Id. at amend. $\mathrm{V}$.

115. For an analogous discussion on similar passages, see supra notes 50 and 51 and accompanying text.

116. Cf. Rawls, supra note 112, at 11 .

117. U.S. CONST. art. I, $\$ 9$, cl. 8.

118. Id. at amend. III.

119. Rawls, supra note 112 , at 24. 
weakened to the extent that alternative methods of interpretation will promote these values to virtually the same extent and accomplish other social goods as well. Insofar as the common law method of development by imcremental change continues to play a major role in constitutional interpretation, for example, stability and predictability can to some extent be protected without sacrificing the law's capacity for growth. Despite the fact that common-law-like interpretations far removed from the origination are often not originalist, they will not always be subject to strong stability and predictability criticisms. ${ }^{120}$

The case for originalist interpretation on grounds of stability and predictability values is further weakened by the very fact that the interpretations that produced modern constitutional law were not originalist. Even assuming that considerations of stability and predictability ought to have led the court to refram froin such interpretations in the past, it does not follow that they justify a return to originalisin at this stage in constitutional evolution. Quite the opposite follows: the wholesale overturning of doctrines required by thoroughgoing originalism would obviously be destabilizing and, at least in the short run, unpredictable.

Finally, not all nonoriginalist interpretations of constitutional provisions seriously threaten stability and predictability values. The rules of constitutional law are not the sole, or even an important, cause of individual and social expectations. Expectations, and therefore what counts as "stability," change as society changes. Consequently, the "old rules" that originahism would yield imght not parallel, and may even defeat, social expectations.

Consider, for example, the situation when the Supreme Court began seriously scrutinizing sex discrimination claims. ${ }^{121}$ By that time, certain forins of sex discrimination had been made unlawful by federal and many state statutes. ${ }^{122}$ Moreover, the behef that sex discrimination was improper was both widespread and growing, though it was clearly not held by everyone. ${ }^{123}$ Given this statutory and social context, it is at best

120. For an attempt to explain and to some extent justify constitutional development in much this way, see Bennett, supra note 14 , at $474-91$.

121. This development began with Reed v. Reed, 404 U.S. 71 (1971), and escalated quite drastically in Frontiero v. Richardson, 411 U.S. 677 (1973).

122. See, e.g., 42 U.S.C. $\$ 2000$ e-2 (1982) (unfair labor practice to discriminate on basis of sex); CAL. Civ. Code $\$ 51$ (West 1982) (same); see also Murray \& Eastwood, Jane Crow and the Law: Sex Discrimination and Title VII, 34 GEO. WASH. L. REV. 232 (1965). "As of August, 1965, ten states and the District of Columbia had fair employment laws that prohibited discrimination on the basis of sex." Id. at 233 n.8.

123. For example, The President's Commission on the Status of Women was established in 1961, and reported in 1963. There followed at the federal level an attempt to implement its recommendations. By October, 1965 forty-five states had established state commissions on the status of women. These commissions and the historical evidence of concern over discrimination against women are discussed in Murray \& Eastwood, supra note 122 at 232-33, and in Brown, 
unclear whether the Court's refusal to hear sex discrimination claims would have had the effect of stabilizing or destabilizing legal principles or social attitudes relating to sex discrimination. ${ }^{124}$

Many examples might be given of originalist interpretations that potentially contradict stability and predictability values. Originalism would lead to the conclusion that the fifth amendment's "taking" clause is applicable only to the federal government and not to the states, ${ }^{125}$ and perhaps that the Constitution prohibits only the states and not the federal government from impairing the obligations of contract. ${ }^{126}$ Yet the very expectation and rehance interests which support originalist interpretation of these provisions also support nonoriginalist extension of the coverage of each if, as seeins very likely, people take action in reliance on the belief that property and contracts are secure from takings and impairments by all governments.

Similar arguments could be made about notions of governinent employment as "property" that camiot be taken away without "due process of law."127 Suppose government employment plays a role in people's lives today that is similar to the role more traditional forms of property played in the hives of the framers. Under this hypothesis, the Court might decide that the nonoriginalist conclusion would better promote stability and predictability, and rule that the involuntary termination of einployment does require due process.

The argument for nonoriginahist interpretation is even stronger when the Court considers issues created by teclinological advances. For example, cars and telephones could not possibly have been witlin the ambit of the fourth amendment; yet if society comes to believe it can rely on the privacy of its glove compartments and telephone conversations, ${ }^{128}$

Emerson, Falk \& Freedman, The Equal Rights Amendment: $A$ Constitutional Basis for Equal Rights for Women, 80 YALE L.J. 871, $872-74$ (1971).

124. The question is further clouded by the fact that judicial intervention was by no means unpredictable. Law review articles had for some time urged the Court to intervene in sex discrimination cases. See, eg., Crozier, Constitutionality of Discrimination Based on Sex, 15 B.U.L. Rev. 723, 752-55 (1935); Murray \& Eastwood, supra note 122, at 235-42. But see Note, Sex, Discrimination, and the Constitution, 2 STAN. L. REv. 690, 718-27 (1950) (urging legislative solution to gender discrimination problems).

125. It is unclear whether the Supreme Court's restrictions on state takings of property derive from incorporation of the fifth amendment provision into the fourteenth amendment, or from the view that the fourteenth amendment's due process clause happens to have exactly the same meaning as the fifth amendment's taking clause. See J. Nowak, R. Rotunda \& N. Young, supra note 61, at 456. It is clear that the Court applies the same standards to alleged federal and state takings and that in state cases it uses the "takings" vocabulary. See, e.g., Webb's Fabulous Pharmacies, Inc. v. Beckwith, 449 U.S. 155, 159-65 (1980).

126. See supra note 8.

127. See Goldberg v. Kelly, 397 U.S. 254, 262 n.8 (1970); Reich, The New Property, 73 YalE L.J. 733 (1964).

128. See, e.g., Katz v. United States, 389 U.S. 347 (1967). 
the Court inay decide that a nonoriginahist interpretation of the search warrant requirement better protects stability and predictability.

\section{The Virtues of Change and Unpredictability}

Conceding that change and unpredictability are undesirable when they defeat expectations or cause distress, the very saine unpredictable changes may nevertheless be good im other ways for individuals or societies. For exainple, it is possible that change and unpredictability proinote individual growth, flexibility, and creativity by forcing people into patterns of constantly modifying adaptive behavior. These changes in behavior often will lead to social benefits, such as flourishing arts, rapid technological innovation, and prospering econornies.

Creating social conditions im which individuals are often confronted with change and unpredictability inay also serve to curb the power of presuppositional belief, and thus provide at least a partial check on the growtli of wliat soine call false consciousness. ${ }^{129}$ Subjecting people to a constantly clianging society and strongly inducing thein towards new experiences reduces the probability they will never question their beliefs, including tliose beliefs whicli are byproducts of class- or other dominance-relationships within society, or sinply of ignorance.

These values liave many implications for constitutional interpretation. While some liave gone so far as to urge the Court constantly to cliange its interpretation of the Constitution just for the sake of cliange, ${ }^{130}$ a inore modest suggestion is that the Court imterpret the Constitution so as to inaintain society's openness to cliange.

For exainple, these values suggest a broad interpretation of the free speech clause. The Court would of course favor broad (though not necessarily absolute) protection for everything that might reasonably be considered political speecli. It probably would also favor an expansive and decidedly nonoriginalist definition of speecli, based not only on the rational or cogintive value of expressive beliavior but on its emotive, unsettling, and uplifting values as well. The definition would encoinpass all of the arts and entertainments and perliaps certain eleinents of lifestyle clioice. ${ }^{131}$ Last, the Court miglit favor the extension of subsidy riglits for soine speecli-related beliavior, sucl1 as public education and the

129. For recent discussions of false consciousness, see the sources cited supra note 66 .

130. Cf. Unger, The Critical Legal Studies Movement, 96 HARV. L. REv. 561, 611-15 (1983) (discussion of "destabilization rights").

131. Current first amendment case law to some extent does protect the sorts of rights mentioned in the text. See, e.g., Schad v. Mount Ephraim, 452 U.S. 61 (1981) (live nude dancing protected by first amendment); Cohen v. California, 403 U.S. 15 (1971) (four-letter expletives protected by first amendment). The Court has not, however, been willing to extend protection to behaviors that have more to do with lifestyle choice than communication. See, e.g., Kelley v. Johnson, 425 U.S. 238, 247-48 (1976) (regulation of length of policeman's hair does not violate first amendment). 
arts, so that individuals will not be derned access because of their poverty. ${ }^{132}$

More abstractly, one consequence of valuing change more than or as inuch as stability is that the first amendinent becomes a structural tool to proinote society's openness to change. Consequently, the rights of both speakers and audiences are to some extent derived froin the structural imperative that individuals and society must be as open to change as is consistent with other basic social values.

So viewed, the first amendment becones a structural prerequisite both to the supervision-by-elections interpretation of dennocracy and to any atteinpt to justify judicial review by reference to a deep consensus. Rules requiring openness to change will affect consciousness, and therefore, over the long run, will affect both the deep consensus and the preferences of individuals that should ultimately determine the behavior of elected officials.

It is not amiss to note that considerable portions of first amendinent jurisprudence seem consistent with this view. Far nore than narrowly conceived political speech is currently protected. The arts and entertainments are understood to be speech. ${ }^{133}$ Speech-subsidy and lifestyle issues have at least reached the Court's agenda, even if the claims were not favorably received. ${ }^{134}$ The important exception in first amendment jurisprudence to the normal rule barring third-party standing can be understood as a necessary implication of this structural imperative. ${ }^{135}$ All free speech claimants are at least to some extent private attorneys general seeking enforcement of everyone's interest in a maximally open society.

132. Cf. Phyler v. Doe, 457 U.S. 202, 221-24 (1982) (school enrollment may not be denied to children illegally in country). But see San Antonio Indep. School Dist. v. Rodriguez, 411 U.S. 1, 50. 51 (1973) (public education financed in part by taxes on property within district does not violate equal protection rights of those living outside district). The real difference between these cases may be that between clear and obvious deprivation of education on the one hand, and unclear and to some extent uncertain relative disadvantagement on the other. In this case the suggestion in the text may have at least some support in the cases. Cf. Sinon, The School Finance Decisions: Collective Bargaining and Future Finance Systems, 82 YALE L.J. 409, $441-60$ (1973) (equality of education should be mionitored through resource allocation).

133. Schad v. Mount Ephraim, 452 U.S. 61 (1981).

134. See, e.g., Kelley v. Johnson, 425 U.S. 238 (1976).

135. For a general discussion of this third-party standing rule, see M. NIMMER, NIMMER ON FREEDOM OF SPEECH: A TREATISE ON THE THEORY OF THE FIRST AMENDMENT $§ 4.11$ [A] at 4 147 to -148 (1984). Seen in this way, the overbreadth doetrine is, as Professor Tribe has argued, an instance of the general principle that the first amendment creates a "buffer zone" for speech, in which the government cannot pursue valid but nonconipelling regulatory interests. See L. TRIBE, AMERICAN CONSTITUTIONAL LAW §12-30, at 723 (1978). My suggestion in the text would interpret buffer zone rights as social, nonpersonal rights enforceable by any member of the society. 


\section{The Promotion of a Good and Just Society Through Constitutional Interpretation}

Even with respect to constitutional provisions as to which originalist interpretation has appeal, strong justification may exist for alternative interpretations. The clearest cases of this kind are those in which originalism would perpetuate the Constitution as a bargain struck by propertied, white males based at least partly on narrow grounds of selfimterest or on that group's arguably parochial interpretation of the deep consensus. Given the unfairness of requiring those who bear the legacy of the original disenfranchisement to resort to the amendment process, the rule-of-law virtues that might support an originalist imterpretation will very often be outweighed by other goods.

While the implications of this critique of originalism depend partly upon how we imterpret the concepts of the originators" "self-imterest" and the "legacy of the original disenfranchisement," its core implications are not very mysterious. For example, the Court should reject any imterpretation of the original understanding of the Constitution's protections of property and contract which would secure unjustified advantages for the propertied classes. Although it is not easy to distinguish justified from unjustified interpretations of terms like "property" or "contract," the difficulty of the task does not excuse its undertaking. The Court's rejection in the Blaisdell ${ }^{136}$ case of what was probably the original understanding of the impairment clause was well within reason by this test. ${ }^{137}$ So also was its eventual withdrawal from econormic due process, for although its withdrawn interpretation of the fifth and fourteenth amendments was not based on originalism, ${ }^{138}$ it was protectimg property to an extent well beyond that required by social welfare. ${ }^{139}$

Furthermore, current members of groups excluded from the original

136. Home Bldg. \& Loan Ass'n v. Blaisdell, 290 U.S. 398 (1934).

137. Originalism, of course, was the basis of Justice Sutherland's well-known dissent in Blaisdell:

If it be possible by resort to the testimony of history to put any question of constitutional intent beyond the domain of uncertainty, the [history reviewed earlier in the dissent] leaves no reasonable ground upon which to base a denial that the [contract clause] was meant to foreclose state action [of exactly the sort at issue in Blaisdell]. . . .

Blaisdell, 290 U.S. 398, 465 (Sutherland, J., dissenting).

138. For a contrary view, see B. SIEGAN, supra note 38, at 91-108.

139. Deciding whether a proteetion of property rights goes beyond what is required by social welfare depends on whether less protection would significantly reduce the size of the social welfare pie, by, for example, significantly reducing incentives to work or to risk capital. If not, the greater increment in protection simply protects the rich and hurts the poor without justification.

One might object to this analysis by claiming that property rights deserve protection on nonconsequentialist, inoral grounds as well. Even if true, this claim does not resolve the debate, for the question would remain to what extent inorality justifies protecting property. Much has been written on these questions. See e.g., Bebchuk, supra note 43, at 677-84; see also Kennedy \& Michelman, Are Property and Contract Efficient?, 8 HofSTRA L. REv. 711, 748-70 (1980). 
participation, most obviously blacks and women, should be protected by interpretation of the equal protection clause irrespective of to what extent such protection was contemplated by the original understanding. Once again, while this theory underdetermines the kind and degree of protection, the basic principle holds, and questions of kind and degree can be (as they im fact are) decided on the basis of further arguments over welfare, ideals, and justice. Neither the Court nor scholars have the slightest reason for embarrassment over the holding in Brown v. Board of Education, ${ }^{140}$ notwithstanding that the original understanding may have been that the equal protection clause did not ban segregation. ${ }^{141}$

The related concepts of the originators' self-interest and the legacy of disenfranchisement miglit be interpreted even inore broadly to justify a wide range of nonoriginalist interpretations. An intermediate extension of these concepts might support the claim, for example, that the original understanding of the Constitution's allocation of authority between the federal and state governments should be rejected insofar as it reflects the originators' attempt to protect property rights beyond what can be justified by the social value of property. A similar extension might support a claim for special protection under the equal protection clause for any ethnic group that finds itself the subject of ethnic-based discrimination, if that group was not represented at the origination. ${ }^{142}$

Extended fully, the concepts of self-interest and the legacy of the original disenfranchisement might justify nonoriginalist interpretation on belialf of anyone alive today with interests, values, and concepts of self different from those held by the originators. No one alive today consented to the original understanding, and to the cxtent that our interests, values, and self-conceptions were not represented at the origination, it is unjust to bind those of us who are ahve today to that understanding. An argument supporting special equal protection rights for gay people inight be inade, for example, on the premise that the originators did not represent people like today's gay population. Perhaps hoinosexuality was not as important a dimension of people's self-identity as it appears to be today. Perhaps gay people were not then wilhing to form an interest group because this would have required a public announcement of their sexual preferences. Whatever the reason, it is difficult to believe that the originators even represented people who, hike a great inany of us alive today, strongly value tolerance of sexual preference.

These arguments based on the originators' self-interest and the legacy of disenfranchisement probably would persuade many people who

140. 347 U.S. 483 (1954).

141. See R. BERGER, supra note 2, at 117-33.

142. This extension would obviously hold if few people of that ethnicity had emigrated to the United States as of the time of the Constitution's drafting. 
would reject arguments based squarely on welfare, ideals, or justice. For these people, the arguments would be persuasive because they invoke norms of procedural fairness. Human instinct suggests that people can recognize an uurepresentative or unfair process but are less certain about what is good for society, or what justice requires.

While this instimct is understandable, it is unfounded. Our ideas about representation and fair process depend at least impticitly on arguments or assumptions about "substantive" morality, and not the other way around. ${ }^{143}$ When people resort exclusively to process-conceptualizations of value, they cling to an anchor that is itself adrift. This should be clear from my sexual-preference extension of the "legacy" argument, as well as from the infinite number of possible extensions of Dean Ely's "process-based" theory of judicial review. ${ }^{144}$

The point is not that these arguinents are illegitimate or improper, but that they are really about goodness and justice. It is objectionable to give the Constitution meanings that perpetuate self-interested distributions of property because they would today produce distributional advantages for the relatively rich that today cannot be justified on the basis of any increase in aggregate social or average welfare. ${ }^{145}$ From the point of view of justice, the nonoriginalist interpretation is preferable because a decision today that is reasonably neutral (i.e., less self-interested) with respect to coinpeting interests is preferable to perpetuation of the quite nonneutral original position.

The objections to interpreting the Constitution to perpetuate the disenfranchisement of blacks or other ethnic groups probably have less to do with utilitarianism than with ideals and requirements of justice. Welfare calculations are not irrelevant, and one might well conclude that aggregate social welfare is increased by extending constitutional protection beyond what originalism would grant, given the likely intensities of preference of discriminators and victims of discrimination, the potential costs of discrimination to social stability, and so on. Moral intuitions on this issue outrun utilitariamsm, however, for most people would probably find even inore offensive a regime founded on highly valued racial prejudice by an overwhelming majority against a group that had learued to be content with its lot, despite the likelihood that the perpetuation of

143. See supra text accompanying notes $26-35$.

144. Many commentators have made this point. See Brest, supra note 27, at 131; Chemerinsky, The Price of Asking the Wrong Question, 62 TEx. L. REv. 1207, 1222-23 (1984); Dworkin, supra note 11, at 515-16; Michelman, Welfare Rights in a Constitutional Democracy, 1979 WASH. U.L.Q. $659,674-80$.

145. Given the inevitable choice between an originalist interpretation allowing the relatively rich to retain this unjustified imcrement or a nonoriginalist interpretation allowing its transfer to the relatively poor, courts should choose the latter, if only because of the likelihood that money has marginally declining utility. See supra note 139. 
discrimination in these circumstances would produce greater social welfare than would its elimination.

The immorality of racial and ethnic discrimination is a widely shared inoral value. The ideal has been forged in large part by books, films, and television programs with obvious if sometimes implicit moral messages-stories about slavery, Nazi Germany, school segregation, lynchings, Japanese "relocation centers," massacres of American Indians, and so on. The paradigm of evil common to such stories has becoine part of our culture, and therefore part of both our national and individual identities. While the ideal coexists with baser instincts and is lardly analytically precise, the crucial facts are that it does exist, it is important, and to the extent that racial or ethnic discrimination would fall short of our ideal today, it is sufficient justification for a nonoriginalist interpretation of equal protection.

Furthermore, justice demands racial neutrality because nonneutrality often proceeds from behiefs that people of one race are less wortly than people of others. ${ }^{146}$ The requirements of justice in this regard are controversial and certainly underdetermine constitutional doctrine, but these are not sufficient reasons for refusing to follow them. To the extent originalism falls short of our interpretation of the requirements of justice today it should be rejected. These issues too can be determined the way moral issues always are-through moral arguinent.

The point is that any atteinpted justification of originalism on grounds of goodness and justice presents questions of substantive political morality to be judged as best we can by our contemporary standards. Process defects often will be important evidence bearing on the relevant moral question, but they do not constitute that question. Ambiguities in the virtually impossible welfare calculations that would be necessary to measure the social justification of originalist property protections can rightly be affected by the fact that the originators had the motive and opportunity for actimg in self-interest. The same is true of assessments of the relative justice (neutrality) of originalist and nonoriginalist interpretations of this issue. ${ }^{147}$ The fact and extent of racial and ethnic disenfranchiseinent tell us quite a bit about how safe it might be to assume that originalist judgments reflect our ideals or were based on race-neutral perspectives, even though they admittedly do not tell us how to interpret these ideals or justice requirements.

We 1might extend this discussion for the purpose of illustrating the inany kinds of inoral claims that counterbalance and arguably outweigh

146. Justice may require racial neutrality for other reasons as well. See, e.g., Sunstein, supra note 109 , at 133-38.

147. Blacks, women, and nonproperty owners were not eligible to vote or participate in the ratification process. See supra notes $44 \& 48$. 
whatever virtues originalism might have. In substance this would involve rearguing all constitutional cases. I have chosen obvious and, I hope, forceful examples. The basic point, however, is generally apphicable to all constitutional claims. Substantial welfare-based claims exist for extension of federal legislative jurisdiction beyond, for example, what the originators might have intended the commerce clause to convey. ${ }^{148}$ The case for special protection for women and gays may be less compelling than for blacks, but it is certainly not weak. ${ }^{149}$ Substantial bases exist for much more radical interpretations as well. And so it goes.

\section{VI}

\section{SOME Concluding ObServations}

\section{A. Predicting the Past}

Proponents of originalism have always found two arguments particularly telling. First, it is unthinkable that the Court might interpret a very clear textual provision, like the age prerequisite for the presidency, to mean something other than what it clearly says, and the Court has not done so. ${ }^{150}$ Second, it is unthinkable that very soon after a constitutional amendment were ratified the Court would interpret it as meaning something quite different from what it was intended to mean, and the Court likewise has not done so. ${ }^{151}$ Originalists seem to think these examples show that the intuitions supporting originalisin are sound and generalizable to all cases. What they in fact show is that moral argument is tricky business, and that attention to detail and context pays off.

As noted earlier, the case for originalism based on the rule-of-law virtues is in fact strongest with respect to contract-like provisions, clauses that are constitutive of institutions, and clear and specific provisions im general. ${ }^{152}$ There are usually good rcasons for giving these provisions their plam meaning. Furthermore, there will rarely be strong welfare, ideal, or justice rcasons for according these provisions other meanings.

When there have been substantial counterarguments, however, the

148. Without federal intervention, the market would tend to limit severely state regulatory power, since goods produced in nonregulating states would undersell those produced in states whose regulations added to the costs of production. Presumably, this is the real basis of the so-called "unfair coinpetition" rationale for extending federal commerce power in cases like United States v. Darby, 312 U.S. 100, 114-15 (1941). To the extent that the inarket-suppressed state regulationslike banning child labor or requiring minimum wages-are welfare enhancing (as inany believe), welfare arguments therefore support such extensions of federal power.

149. See, eg., Note, An Argument for the Application of Equal Protection Heightened Scrutiny to Classifications Based on Homosexuality, 57 S. CAL. L. REV. 797 (1984).

150. See, eg., Monaghan, supra note 2, at 362-63.

151. Cf. id. at 375 (early courts should have used originalist nethodology in interpreting Constitution).

152. See supra text accompanying notes 113-19. 
Court has been receptive. The original understanding of the security provided by the impairments clause has been undercut, for exainple, ${ }^{153}$ and the Court has in general been careful not to overprotect property rights. ${ }^{154}$ Conversely, the takings clause has apparently been applied to the states, ${ }^{155}$ and the basic principle of nonimpairment of contracts has been applied to the federal government, ${ }^{156}$ notwithstanding the former was certainly not, and the latter probably not, within the original understanding.

The Court has not changed the plain meaning of any of the clear and specific provisions of the Constitution, and it has been particularly sensitive not only to plain meaning, but also to original intention and precedent in interpreting the provisions that are constitutive of institutions. ${ }^{157}$ Should a case arise presenting sufficiently substantial counterarguinents to this approach, the Court should and probably could accept thein. ${ }^{158}$

Preservation of the integrity of the amendment process is strongly supported not only by stability of expectation values but by other considerations as well. Given the right point in history, a constitutional crisis could result if it were unclear which institution had the final say. As far as virtually all conceivable ainendments are concerned, having a clear rule of institutional finality is more important than either the substance of the amendinent or the choice of imstitution assigned the task. The Constitution provides a relatively clear rule, and it assigns this task to institutions other than the Supreme Court. Moreover, the frainework established in the document is, for rather obvious reasons, by and large better justified than an alternative hike giving the Court final say over the

153. See supra notes $136-37$ and accompanying text.

154. The reference here, of course, is to the Court's well-known withdrawal from economic due process. See, e.g., G. GunTHER, CASES AND MATERIALS ON CONSTITUTIONAL LAW 528-44 (10th ed. 1980).

155. See supra note 125.

156. See supra note 8.

157. A recent example of the Court's preoccupation with constitutional text, history, and original intention in dealing with imstitutional questions is Immigration \& Naturalization Serv. v. Chadha, 103 S. Ct. 2764, $2780-88$ (1983), which struck down the so-called legislative veto. The Court's use of these interpretive methods seems plainly based on the high value the Court placed on stability of institutional definitions and roles as compared with competing values. "The hydraulic pressure inherent within each of the separate Branches to exceed the outer limits of its power, even to accomplish desirable objectives, must be resisted." Id. at 2784. Similar values underlie the authoritativeness accorded historical institutional practices in cases involving intrabrancls constitutional disputes: "a systematic, unbroken, executive practice, long pursued to the knowledge of the Congress and never before questioned . . . may be treated as a gloss on 'Executive Power' vested in the President by $\S 1$ of Art. II." Dames \& Moore v. Regan, 453 U.S. 654, 686 (1981) (quoting Youngstown Shect \& Tube Co. v. Sawyer, 343 U.S. 579, 610-611 (1952)).

158. To take an extreme example, imagine that a bizarre disease suddenly killed everyone over the age of 35 and that a presidential election was too imminent to permit the amendment process to work. 
"legality" of constitutional amendments. ${ }^{159}$

Given these considerations, it would be extremely difficult to justify a judicial interpretation of a recently enacted amendment that substantially deviated from its plain or clearly intended meaning. Such an interpretation could be justified ouly by extreinely coinpelling arguments. Arguinents based on welfare are very unlikely to persuade, given that the passage through the difficult rites of amendment will normally be strong evidence that the amendment is welfare-enhancing. Ideal-based argunients are similarly unlikely, since the amendınent's very passage will indicate that it embodies at least the relevant contemporary ideals.

The requirements of justice are the most likely source of a strong argument, and the sort of ainendinent likely to trigger it is one seriously disadvantaging a discrete and insular racial or ethnic minority. What the Court ought to do in such a case is either restrictively interpret the ainendment or hold that it exceeds the grant of the amendment power and is therefore invalid. The very example posits a case of such extreine (and unlikely) social disintegration, however, that it is unlikely the Court could do so and survive as an institution. ${ }^{160}$

The strength of the arguinents against the Court's deviating froin originalist interpretation of anendments decreases with the passage of time. Deviations thirty years after the passage of the amendment pose no threat of constitutional crisis and hittle threat of serious demoralization. Meanwhile, welfare and ideal considerations will have changed, and justice considerations may be implemented without contributing to social disintegration or destruction of the Court. Moreover, as Professor Brest has argued, there are simply good reasons for having an institution like judicial review that can nrake the case-by-case judgments and sinall changes for which the amendment process is not well suited. ${ }^{161}$

In sum, the intuition that it would be improper for the Court to change the ineaming of a recently enacted amendment is well founded in inoral reasoning. But as with the more general case of following the meaning of clear and specific clauses, these good reasons do not support originahsm in general, and, once agam, the Court's behavior corroborates this observation.

The Court has interpreted the first amendment to protect rights far beyond what was originally intended, and as I have previously suggested, first ainendment jurisprudence as a whole is not seriously inconsistent

159. Whatever one makes of the controversy over the respective roles of appointive versus electorally responsible institutions, if one or the other must be chosen for this ultimate responsibility, it seeins obvious that the electoral choice is better justified. The considerations bearing on this conclnsion are discussed briefly in the text that follows.

160. The possibility of institutional destruction, if clear, becomes in turn an argument for judicial tolerance of the discriminatory amendment.

161. See Brest, supra note 1, at 236. 
with the hypothesis that change and unpredictability have been recognized as virtues as well as vices. ${ }^{162}$ Chiefly in response to welfare-based arguments, the Court has expanded federal power vis-a-vis the states well beyond the original understanding of the commerce clause. ${ }^{163}$ In many contexts of constitutional interpretation, it arguably has taken account of changes in social expectations, thus proinoting stability of social expectation by changing the Constitution's meaning. ${ }^{164}$ Finally, it has extended the equal protection clause in ways that were not originally intended, most importantly by banning racial segregation ${ }^{165}$ and subjecting gender discrimination to heightened scrutiny. ${ }^{166}$

The correspondence between the development of constitutional law and many of the firmer conclusions that have emerged froin this analysis obviously does not establish that the roles that the theory might propose for the Court are normatively proper. The "theory" that has emerged in this Article was not desigued for this task, but for the inore himited ones of exploring whether constitutional interpretation without inoral reasoning is justifiable and of testing the goodness and justice of originalisin and nonoriginahism in general. The larger task requires, as I have repeatedly einphasized, an analysis of democratic theory as it bears upon the allocation of authority among contemporary institutions.

I will confess, however, that I find the correspondence a pleasing one. It is always gratifying when a nornnative theory about a normative institution bears some correspondence to the actual behavior of that institution. It is also rewarding to be able to beheve that the Justices of the Supreme Court have at least to some extent shaped constitutional development to reflect some of our inore widely held intuitions about a good and just society.

\section{B. Reflecting on the Future}

The theory proposed in this paper may be assailed for justifying the Court's pursuit of moral visions quite different from those of prior courts. This is by and large an unfair criticism. It is quite true that the concepts of goodness and justice are so broad and their measurement so imprecise that different Justices may legitimately hold different conceptions of what they imply. These stateinents are simply facts about moral reasoning in our times. Given my own behefs about goodness and justice and my fears for the future of constitutional development, I wish it were otherwise, but it is not.

162. See supra text accompanying notes 129-135.

163. See supra note 148.

164. See supra text accompanying notes 133-135.

165. Brown v. Board of Education, 347 U.S. 483, 495 (1954).

166. Craig v. Boren, 429 U.S. 190, 204 (1976). 
This does not suggest that virtually any decision might plausibly be found good for persons or society. A great parade of unlikely decisions, like the overruling of Brown v. Board of Education, ${ }^{167}$ would probably be too difficult to justify on moral grounds. Of course, the goodness and justice of institutions like judicial review are of secondary importance to that of society as a whole, and one can miagine an unfortunate course of future judicial decisions that would justify seeking an amendment eliminating judicial review. ${ }^{168}$ The institution of judicial review has great social value, however, and deserves our support up to the point where clear evidence and not just speculation shows that it is producing great harms or imjustice.

To the extent that legal scholars can influence the future at all, it is by clarifying basic constitutional concepts, arguing about the good and just society, and discussing how best to produce that society through constitutional interpretation. Scholars should also engage in criticism and, if necessary, political action to curb judicial abuses, and should teach the next generation of Justices to beware of easy answers and to concern themselves with what is good and just. Bad decisions of the Court need to be branded as sucli. Most of all, no future law student should be led to beheve that "originalism" casts the shightest shadow on the legitimacy of decisions like Brown v. Board of Education. ${ }^{169}$

167. 347 U.S. 483 (1954).

168. Not even an amendment specifically protecting a "politically liberal" agenda of constitutional rights would serve the end of restricting the power of a court as indifferent to goodness and justice as this scenario postulates, since the Court presumably would pay little or no attention to it.

169. 347 U.S. 483,493 (1954). 